\title{
Skarn-style alteration in Proterozoic metasedimentary protoliths hosting IOCG mineralization: the Island Dam Prospect, South Australia
}

\author{
William Keyser $^{1}$ (D) Cristiana L. Ciobanu ${ }^{1} \cdot$ Kathy Ehrig $^{2,3} \cdot$ Marija Dmitrijeva $^{1} \cdot$ Benjamin P. Wade $^{4}$. \\ Liam Courtney-Davies ${ }^{1} \cdot$ Max Verdugo-Ihl ${ }^{1} \cdot$ Nigel J. Cook $^{3}$
}

Received: 6 August 2021 / Accepted: 21 January 2022 / Published online: 27 February 2022

(c) The Author(s) 2022

\begin{abstract}
New mineralogical, geochemical, and geochronological data are presented for the Island Dam prospect, Olympic $\mathrm{Cu}-\mathrm{Au}$ Province, South Australia. Skarn assemblages comprising actinolite/phlogopite + K-feldspar + magnetite suggest the presence of calcareous protoliths at Island Dam and indicate high-temperature alkali-calcic alteration in the early stages of IOCG mineralization, as seen in other deposits in the region. Dating of lamellar hematite intergrown with $\mathrm{Cu}$-Fe-sulfides allows the timing of the alteration-mineralization event to be constrained at $1594 \pm 28 \mathrm{Ma}$, contemporaneous with the $\sim 1.59 \mathrm{Ga}$ IOCG mineralization event recorded across the eastern Gawler Craton. The host metasedimentary sequence can be correlated to the Wallaroo Group based on lithology and fabrics, and stratigraphically by an underlying 1850 Ma Donington Suite granite and the new $\mathrm{U}-\mathrm{Pb}$ ages for superimposed mineralization. Oscillatory zoned silician magnetite in skarn displays a trace element signature comparable to that observed in the outer shell of the Olympic Dam deposit and the nearby Wirrda Well prospect and is consistent with early stages of IOCG mineralization. The geochemical signatures of hematite from skarn and banded Fe-rich metasedimentary rocks share a common enrichment in W, Sn, Mo, Th, and U seen in hematite from IOCG-style mineralization across the Gawler Craton. Relative enrichment in $\mathrm{As}, \mathrm{Sb}, \mathrm{Ni}$, and $\mathrm{Co}$ is, however, specific to iron-oxides from banded Fe-rich metasedimentary rocks. These features can be attributed to pre-existing iron-rich lithologies.
\end{abstract}

Keywords Olympic Cu-Au Province · IOCG deposits · Skarn alteration · Iron-oxides · Hematite U-Pb geochronology

\section{Introduction}

Iron-oxide copper gold (IOCG) metallogeny encompasses a broad spectrum of alteration styles in rocks hosting $\mathrm{Cu}-\mathrm{Au}-\mathrm{Ag}-(\mathrm{U}, \mathrm{REE})$ mineralization (Barton 2014 and references therein). Irrespective of geological setting, IOCG alteration always features a diverse group of low-Ti

Editorial handling: P. Eilu

William Keyser

william.keyser@nhm.uio.no

1 School of Chemical Engineering and Advanced Materials, The University of Adelaide, Adelaide, SA 5005, Australia

2 BHP Olympic Dam, 10 Franklin St., Adelaide, SA 5000, Australia

3 School of Civil, Environmental and Mining Engineering, The University of Adelaide, Adelaide, SA 5005, Australia

4 Adelaide Microscopy, The University of Adelaide, Adelaide, SA 5005, Australia iron-oxides as the dominant component ( $>10 \%)$. Iron-oxides are represented by high-temperature (HT) magnetite- and low-temperature (LT) hematite-rich endmembers, with transition from magnetite to hematite accompanying ascent, cooling, and acidification of voluminous, highly saline hydrothermal fluids of likely magmatic origin (Oreskes and Einaudi 1992; Bastrakov et al. 2007; Williams et al. 2010).

Fluid-rock interactions generate regional-scale IOCG footprints with diagnostic mineral assemblages that define alteration halos. These can be sub-divided into (i) early HT $\mathrm{Na}(\mathrm{Ca}-\mathrm{Fe})$ alteration (albite + calcsilicates + magnetite); (ii) Fe-K alteration (K-feldspar and/or biotite-magnetite); and (iii) late LT hydrolytic (sericite-chlorite) hematitecarbonate-quartz alteration + mineralization (Hayward and Skirrow 2010). Recognition of one or more of the alteration types provides important information about the space-time evolution of IOCG mineralization at the regional- to deposit-scale and may be a valuable indicator of economic potential (Hitzman et al. 1992). Recognition and correct interpretation of alteration facies is crucial for 
the application of alteration signatures in exploration to systematically vector towards mineralization.

The Olympic $\mathrm{Cu}-\mathrm{Au}$ Province, eastern Gawler Craton, South Australia, is one of largest Mesoproterozoic IOCG provinces worldwide (Hayward and Skirrow 2010; Reid 2019). Mineralization is attributed to craton-wide magmatic-hydrothermal activity at $\sim 1.6 \mathrm{Ga}$ (Skirrow et al. 2007; Allen et al. 2008; Cherry et al. 2018; CourtneyDavies et al. 2020a). The province hosts a range of IOCG mineralization systems in diverse geological settings, the best known of which are hosted by hematite breccias within Mesoproterozoic volcanic to granitic lithologies such as the giant Olympic Dam deposit (Ehrig et al. 2012, 2017). Calcic skarn-IOCG mineralization is, however, known throughout the province at Punt Hill (Reid et al. 2011) and Moonta-Wallaroo districts (Conor et al. 2010; Reid et al. 2011; Ismail et al. 2014). In addition to calcareous units, iron-rich horizons interpreted as banded iron formation (BIF) are also present within metasediments (Conor et al. 2010; Keyser et al. 2017; Geological Survey of South Australia, 2019; https://map.sarig.sa.gov. $\mathrm{au} /$ ), hinting at the possibility of juxtaposition of IOCG mineralization within terranes hosting older, genetically unrelated Fe-rich lithologies. Such overprinting of mineralization styles has been suggested in the Olympic $\mathrm{Cu}-\mathrm{Au}$ Province based on petrographic and geochronological analysis of iron-oxides at Olympic Dam that predate IOCG mineralization (Courtney-Davies et al. 2020b). The common association between calcareous lithologies and BIFs in older Paleoproterozoic to Archean sedimentary basins makes identification of skarn-type alteration important for interpretation of potential BIF-IOCG relationships.

The Island Dam prospect, $90 \mathrm{~km}$ SE of Olympic Dam, is one such occurrence in which skarn-style alteration is associated with IOCG mineralization within BIF-bearing sedimentary protoliths (Keyser et al. 2017). This contribution uses mineralogical, geochemical, and geochronological data from the Island Dam prospect to provide insights into possible protoliths for mineralized lithologies and discusses their relationships to regional-scale IOCG alteration in the Olympic $\mathrm{Cu}-\mathrm{Au}$ Province. A 3D geological model for the prospect is presented and is complimented by crosssections through the prospect. Mineralization and alteration are characterized from ore textures and compositional data, with emphasis placed on constraining skarn mineral associations, particularly those of the dominant iron-oxides, within different lithologies. Our primary aim is to distinguish between features that can be interpreted as primary, and those that result from hydrothermal overprinting associated with IOCG mineralization. Our results compliment regional geological studies and further constrain the spatial and temporal relationships among individual IOCG prospects across the Olympic $\mathrm{Cu}$-Au Province, as well as the disparate expressions of hydrothermal events associated with IOCG metallogeny in the region.

\section{Geological background}

The Olympic $\mathrm{Cu}-\mathrm{Au}$ Province is roughly defined as $\mathrm{a} \sim 700$-km-long arc-shaped belt of IOCG mineralization in the eastern Gawler Craton (Skirrow et al. 2002, 2007, 2018; Reid 2019). Mineralization is associated with emplacement of the bimodal intrusive rocks of the $\sim 1.6 \mathrm{Ga}$ Hiltaba Suite and coeval Gawler Range Volcanics (GRV; Blissett et al. 1993), representing a silicic-dominated large igneous province (Pankhurst et al. 2011).

Basement rocks within the northern segment of the Olympic $\mathrm{Cu}$-Au Province comprise the $\sim 1.85 \mathrm{Ga}$ Donington Suite granites (Jagodzinski 2005) and metasedimentary rocks of the overlying 1.76-1.74 Ga Wallaroo Group. Older Paleoproterozoic to Archean units such as those exposed in the western and southern Gawler Craton (e.g., the $\sim 2.5 \mathrm{Ga}$ Mulgathing Complex) have been inferred at depth from geophysical modeling (Direen and Lyons 2007). The Wallaroo Group is a diverse package of partially metasomatized lithologies, including finely laminated metasiltstones, arkose, metasandstones, feldspathic-, calcsilicate-, and carbonatebearing metasedimentary rocks, as well as BIF of the Wandearah Formation, and felsic and mafic volcanic rocks of the Weetulta and Matta formations, respectively (Zang 2002; Cowley et al. 2003). Evaporites are also suggested to have been present within the Wallaroo Group based on the widespread occurrence of Na-rich lithologies (e.g., Conor et al. 2010). The extent of the Wallaroo Group is inferred as far north as the Mt. Woods Inlier and as far south as the Yorke Peninsula (Creaser 1989; Cowley et al. 2003). The basement complex throughout the Olympic $\mathrm{Cu}-\mathrm{Au}$ Province is intruded by Hiltaba Suite granitoids, however only in the northern part is it overlain by GRV.

IOCG mineralization occurs within various lithologies across the Olympic $\mathrm{Cu}$-Au Province, including the Donington Suite granite (e.g., Oak Dam, Carrapateena and Wirrda Well), intrusive and metasedimentary rocks of the Wallaroo Group (e.g., Vulcan and Hillside, respectively), and the younger GRV (e.g., Prominent Hill and Acropolis) and Hiltaba Suite granites (Olympic Dam). Mineralization styles are equally as variable, for example, occurring as networks of magnetite-bearing veins at the Acropolis prospect (Krneta et al. 2017a; Courtney-Davies et al. 2019a, b; Dmitrijeva et al. 2019; McPhie et al. 2020), as a vertically plunging breccia pipe at the Wirrda Well prospect (Krneta et al. 2017a; Courtney-Davies et al. 2019a, b; Dmitrijeva et al. 2022), and as skarn replacement of carbonate protoliths at the Hillside deposit and Punt Hill prospect (Reid et al. 2011; Fabris et al. 2018). 


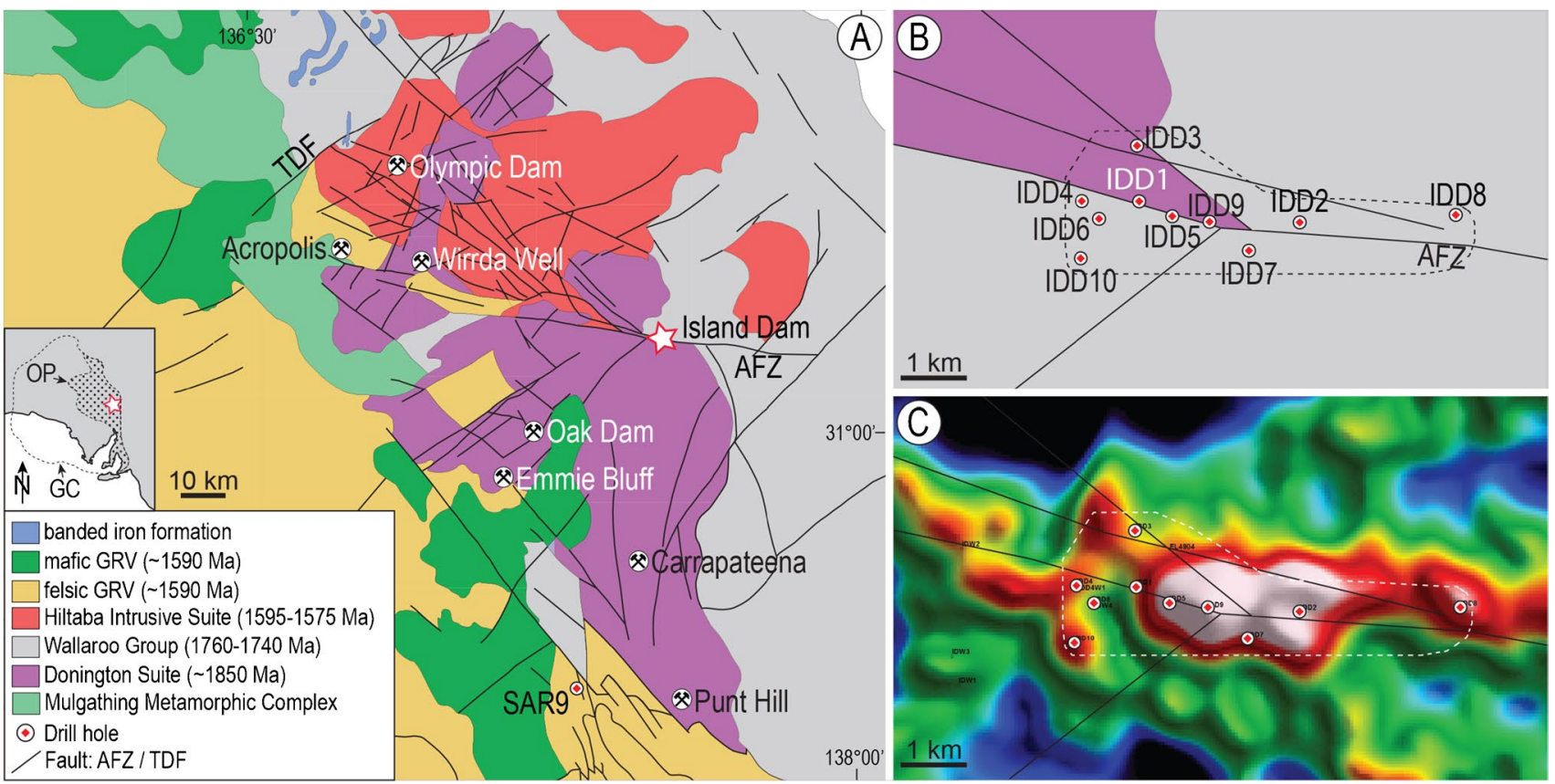

Fig. 1 (A) Basement geology of the central part of the Olympic $\mathrm{Cu}-\mathrm{Au}$ Province showing the location of the Island Dam prospect and surrounding deposits and prospects. Inset shows the location of Island Dam in South Australia and extent of the Olympic $\mathrm{Cu}-\mathrm{Au}$ Province (OP) in the Gawler Craton (GC). AFZ-Andamooka Fault Zone;

Alteration associated with mineralization or well-defined deposit-scale zoning is rarely well preserved due to extensive overprinting. Both $\mathrm{HT} \mathrm{Na}(\mathrm{Ca}-\mathrm{Fe})$ and subsequent $\mathrm{Fe}-\mathrm{K}$ alteration are recognized in the Mt. Woods Inlier and the Moonta-Wallaroo district (Skirrow et al. 2002; Conor et al. 2010). When present, calc-silicates are represented by actinolite, diopside, and trace titanite, allanite, and scapolite (Kontonikas-Charos et al. 2018). Garnet is present where skarn alteration is most pronounced (e.g., at Punt Hill; Reid et al. 2011). Low-temperature hydrolytic alteration is the main mineralizing stage and the dominant alteration type in many of the larger deposits in the Olympic $\mathrm{Cu}$-Au Province (e.g., Olympic Dam and Prominent Hill), but is less common in the Moonta-Wallaroo district (Conor et al. 2010). Skarn-style alteration in various locations throughout the Olympic $\mathrm{Cu}-\mathrm{Au}$ Province is attributable to intrusive relationships between Hiltaba Suite granites (e.g., Tickera Granite; $1583 \pm 7 \mathrm{Ma}$ ) and Wallaroo Group metasedimentary rocks (e.g., Oorlano Metasomatite; Kontonikas-Charos et al. 2014).

In individual deposits, recognition of specific alteration assemblages is often hindered by pervasive overprinting but also by the scale of observation. For example, nanoscale studies have identified alkali-calcic alteration in granite (K-feldspar/hyalophane, epidote) and silician magnetite (K-rich banding and abundant nanoscale inclusions of
TDF-Todd Dams Fault. (B) Geological map of the Island Dam prospect and $(\mathbf{C})$ a total magnetic intensity image showing locations of the ten drillholes in relation to the AFZ and magnetic anomalies. Dashed outline in B and C indicates location of geological model shown as Fig. 3A. Maps sourced from https://map.sarig.sa.gov.au/

(ferro) actinolite + diopside + epidote) at the margins of the Olympic Dam deposit (Kontonikas-Charos et al. 2018; Ciobanu et al. 2019). Although uncharacteristic of the Olympic Dam deposit as a whole, or at least poorly preserved at the macroscale, such alteration represents an earlier stage (magnetite + chalcopyrite + pyrite) of IOCG mineralization . Similarly, clinopyroxene and garnet have been identified as trapped phases within fluid inclusions in quartz from the Torrens $\mathrm{Cu}-\mathrm{Au}$ prospect $\sim 20 \mathrm{~km}$ east of Island Dam (Bastrakov et al. 2007), suggesting an early, albeit largely obliterated, magnetite-K-feldspar-silicate alteration stage.

Recognition of alteration assemblages is further complicated by multiple, superimposed regional metamorphic events. The earliest orogenic event recognized in the Gawler Craton is the $2.47-2.41$ Ga Sleafordian Orogeny (Swain et al. 2005; Halpin and Reid 2016), which led to amphibolite- to granulite-facies metamorphism and the formation of gneissic basement units (e.g., the Mulgathing Complex) onto which younger volcanic and sedimentary rocks were deposited. Similarly high metamorphic grade was attained during the $\sim 1.85 \mathrm{Ga}$ Cornian Orogeny, during which the Donington Suite was emplaced (Reid et al. 2008). The $\sim 1.73-1.69 \mathrm{Ga}$ Kimban major tectonothermal event led to upper-amphibolite- to granulite-facies metamorphism in most regions of the Gawler Craton (Vassallo and Wilson 2002). An exception to this is, however, the eastern Gawler Craton, where low-grade 

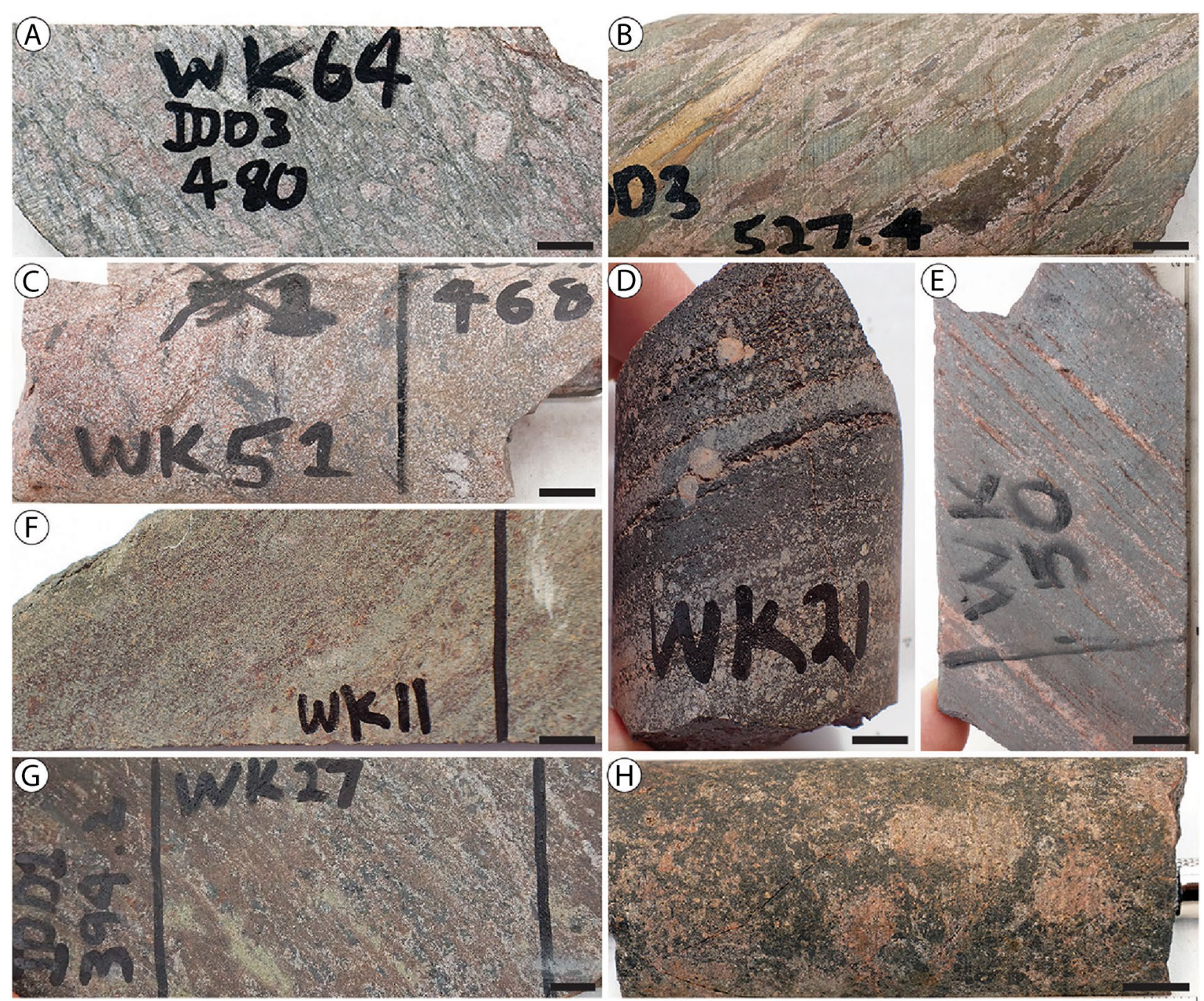

(1)
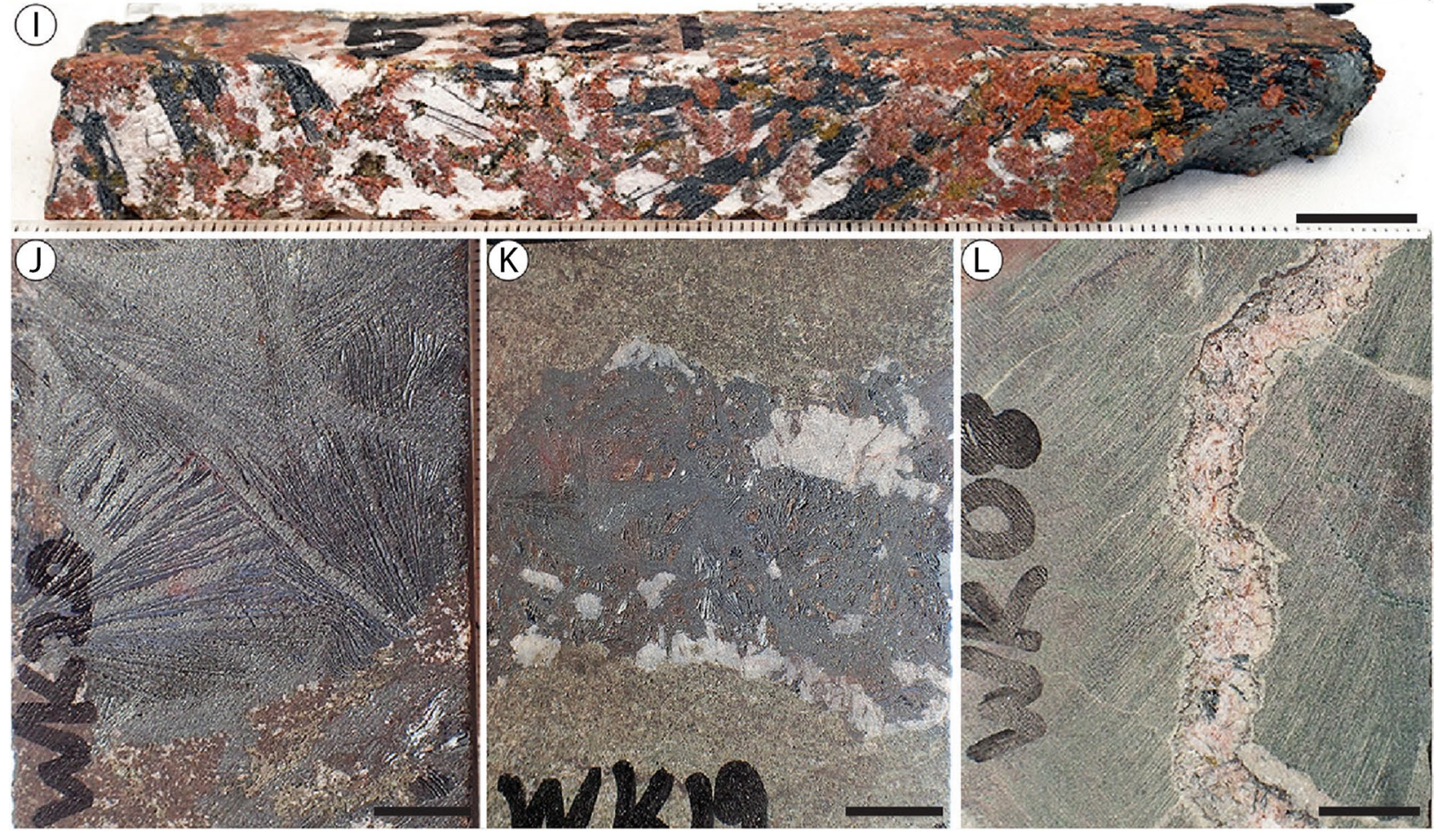
4Fig. 2 Photographs of specimens of representative lithologies from the Donington Suite (A, B) and the Wallaroo Group (C-L). (A) Megacrystic and (B) sheared granites of the Donington Suite. (C) Felsic volcanic rock. (D, E) Iron-rich banded siliceous sediments (arkose). (F-H) Multi-component actinolite/phlogopite (green)-iron-oxide (black)-carbonate (brown)-K-feldspar (pink) skarn lithologies. (I) K-feldspar (red)-calcite (white)-hematite (black)-sulfide (gold) skarn. (J) Pocket and (K) vein containing coarse-grained lamellar hematite associated with carbonates (brown) and quartz (white). (L) Bariterich veinlet containing lamellar hematite and sulfides crosscutting skarn. All scale bars are $1 \mathrm{~cm}$

sedimentary rocks are observed. Dewatering of these rocks may have contributed fluids important for IOCG mineralization (Reid and Fabris 2015).

Mesoproterozoic bedrock across much of the eastern Gawler Craton is cut by an unconformity representing a gap of at least 700 million years, onto which thick sedimentary sequences are deposited across the Stuart Shelf (Preiss 1993). Bedrock is also intruded by the $\sim 820 \mathrm{Ma}$ Gairdner Dolerite (Wingate et al. 1998). Extensive fault reactivation took place during the $\sim 500 \mathrm{Ma}$ Delamerian Orogeny associated with regional-scale fold-thrust complexes (Foden et al. 2006), effectively terminating a rifting event between the Gawler Craton and the eastern Curnamona Province.

\section{Island Dam}

The prospect (Fig. 1), located under a $\sim 250-350 \mathrm{~m}$ cover sequence of sedimentary rocks, is defined by a magnetic anomaly that straddles the E-W striking Andamooka Fault Zone (AFZ), a major fault complex interpreted as an important conduit for IOCG fluid flow during the $\sim 1.6 \mathrm{Ga}$ magmatic event (Skirrow et al. 2007). Ten diamond drillholes (IDD1-IDD10) are located along this anomaly (Fig. 1B, C). Although geological data for the prospect are limited, the variably altered metasedimentary rocks hosting mineralization are correlated with the $\sim 1750 \mathrm{Ma}$ Wallaroo Group (Cowley et al. 2003; Keyser et al. 2017). These are overlain by an unconformable cover sequence of Neoproterozoic sedimentary rocks, including the Nuccaleena Dolomite and the Tregolana Shale. Sensitive high resolution ion microprobe (SHRIMP) U-Pb dating of igneous zircon within a megacrystic granite intersected by drillhole IDD3 yielded an age of $1860 \pm 4 \mathrm{Ma}$ (Jagodzinski 2005), confirming the presence of a Donington Suite basement. Igneous biotite from the same granite yielded an ${ }^{40} \mathrm{Ar} /{ }^{39} \mathrm{Ar}$ plateau age of $1593 \pm 12 \mathrm{Ma}$, interpreted to represent thermal resetting during Gawler silicic-dominated large igneous province magmatism (Skirrow et al. 2007).

\section{Sampling and methodology}

\section{Sample suite}

Lithologies were classified using a combination of drillhole logging, whole-rock geochemistry and petrography. Many of the samples are affected by hydrolytic alteration, which is considered to result from superimposed alteration associated with late-stage fault-(re)activation. The present study is biased towards defining these lithologies using preserved mineral assemblages and textures that predate alteration. Cover sequences are not included in the present study. Sixty-three samples from the 10 drillholes were prepared as $2.5 \times 5 \mathrm{~cm}$ thin-sections and $2.5 \mathrm{~cm}$-diameter polished blocks for petrographic, geochemical, and geochronological study. The list of samples from this study is provided in Electronic Supplementary Material (ESM) Table S1, and schematic representations of drillholes and mean whole-rock geochemical data for representative lithologies are provided in ESM Fig. S1 and Table S2.

\section{Analytical methodology}

Petrographic characterization was performed using transmitted- and reflected-light optical microscopy. Samples were further characterized for micron-scale features and mineralscale compositional zoning using a FEI Quanta 450 scanning electron microscope (SEM) in back-scattered electron (BSE) imaging mode equipped with an energy-dispersive $\mathrm{X}$-ray spectrometer.

A Cameca SXFive Electron Microprobe with five wavelength-dispersive X-ray detectors and running 'PeakSite' software was used for quantitative analysis of amphiboles, micas, feldspars and magnetite. Analytical conditions were $15-\mathrm{kV}$ acceleration voltage with a $20-\mathrm{nA}$ beam current and a defocused $1-\mu \mathrm{m}$ beam. Additional information on analytical methods including standards and minimum detection limits (mdl) is provided in ESM Table S3.

Trace element analysis and grain mapping of iron-oxides, rutile, amphibole and apatite, and $\mathrm{U}-\mathrm{Pb}$ hematite and apatite geochronology were conducted using a RESOlution excimer laser ablation system coupled to an Agilent $7900 \times$ Quadrupole ICP-MS. Trace element acquisition was performed using a laser frequency of $10 \mathrm{~Hz}$, fluence of $3.5 \mathrm{~J} / \mathrm{cm}^{2}$, and a spot size of $13-51 \mu \mathrm{m}$. Internal standard elements used for iron-oxides, rutile, and amphibole and apatite were ${ }^{57} \mathrm{Fe},{ }^{49} \mathrm{Ti},{ }^{43} \mathrm{Ca}$, respectively, assuming ideal stoichiometry. External reference materials were the synthetic basalt glass standard GSD-1G and NIST610. In situ U-Pb hematite dating (Ciobanu et al. 2013; Courtney-Davies et al. 2019a) was performed with a laser frequency of $5 \mathrm{~Hz}$, a spot diameter 


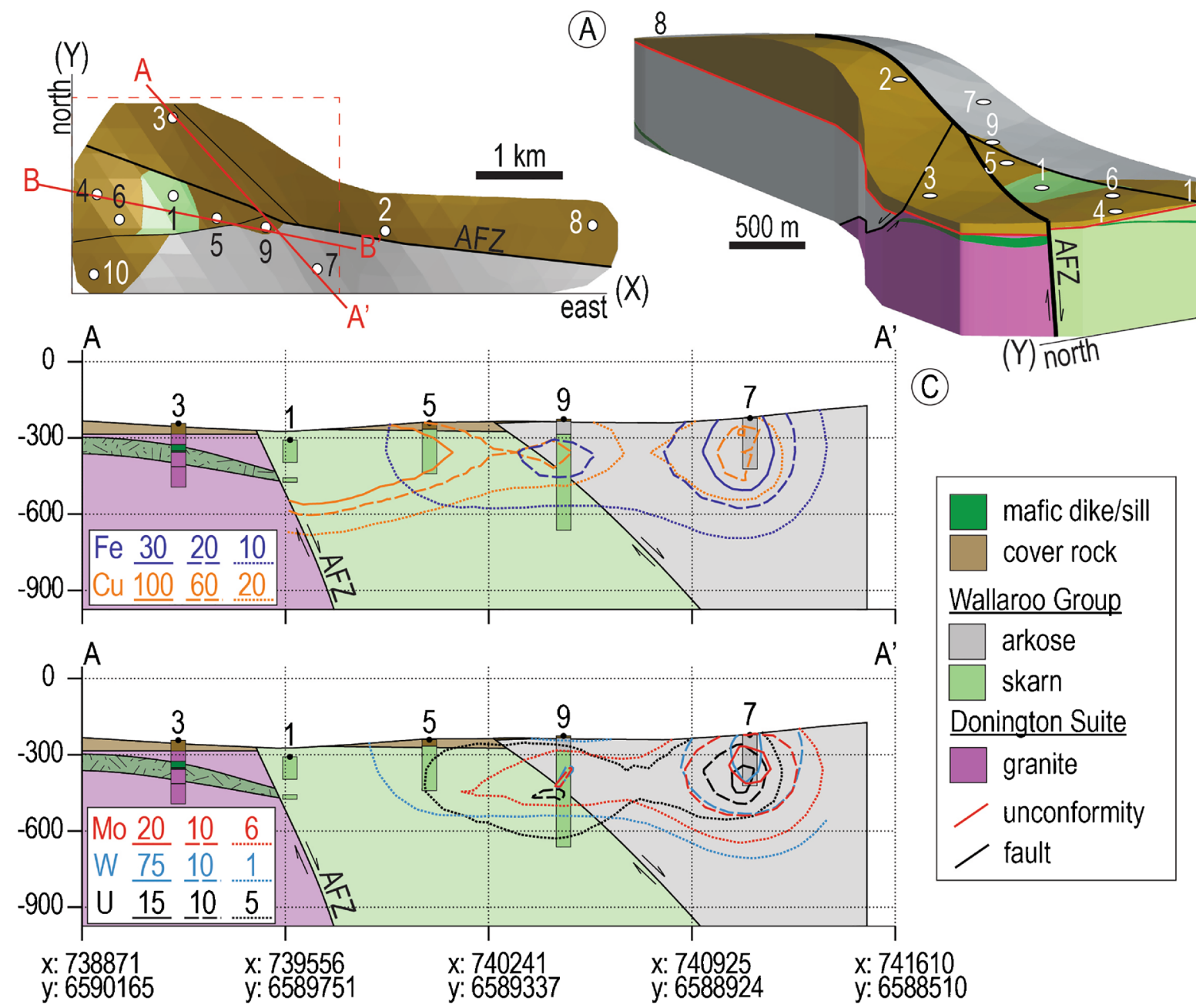

(B)
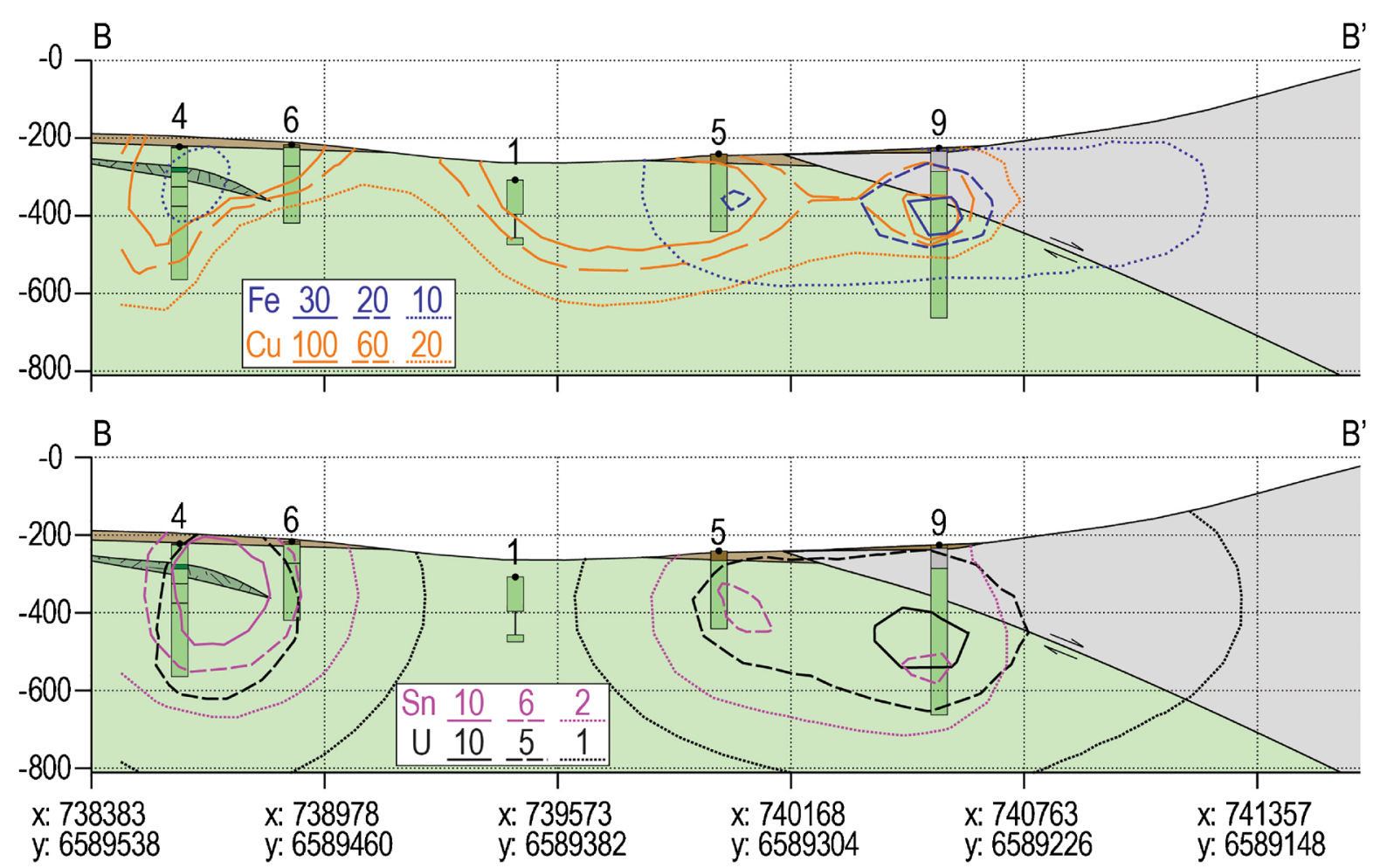
4Fig. 3 Geological model for the Island Dam prospect shown from (A) top and (B) oblique angles. (C) Cross-sections projected through the geological model depicting host lithologies and isolines for $\mathrm{Cu}, \mathrm{Mo}$, W, Sn, U (ppm), and Fe (wt\%) concentrations. Prospect model and cross-sections constructed using Leapfrog Geo 4.5.0 implicit modeling software

of $51 \mu \mathrm{m}$, and a fluence of $4.5 \mathrm{~J} / \mathrm{cm}^{2}$ using the GJ-1 zircon reference material $\left({ }^{206} \mathrm{~Pb} /{ }^{238} \mathrm{U}\right.$ age, $600.7 \mathrm{Ma}$; Jackson et al. 2004) for correction of downhole U-Pb fractionation. Apatite geochronology was performed using a laser frequency of $5 \mathrm{~Hz}$ and a spot diameter of $51 \mu \mathrm{m}$ at a fluence of $3.5 \mathrm{~J} / \mathrm{cm}^{2}$. Reference materials used were the McClure (ID-TIMS weighted-mean ${ }^{207} \mathrm{U} /{ }^{235} \mathrm{~Pb}$ age, $523.51 \pm 1.47 \mathrm{Ma}$; Schoene and Bowring 2006) and Durango $\left({ }^{40} \mathrm{Ar} /{ }^{39} \mathrm{Ar}\right.$ age of $31.44 \pm 0.18 \mathrm{Ma}$; McDowell et al. 2005) apatite standards. All data reduction and creation of LA-ICP-MS element maps were performed using 'Iolite v.2.5' (Paton et al. 2011). All geochronological data are presented using Isoplot 4.1 (Ludwig 2012). Full details of LA-ICP-MS methodology, including reference materials and minimum detection limits, are provided in ESM Table S4. All instrumentation is housed at Adelaide Microscopy, The University of Adelaide.

\section{Spatial 3D-modeling and whole-rock analysis}

Three-dimensional geological modeling was performed using Leapfrog Geo 4.5.0 implicit modeling software. The model was created using core logging data, with numerical interpolations for $\mathrm{Cu}, \mathrm{Fe}, \mathrm{Sn}, \mathrm{W}$, and $\mathrm{U}$ obtained from a whole-rock geochemical dataset of 1934 samples, which were collected and assayed at either 1- or 5-m-long intervals along each drillhole. Methodology for whole-rock analysis is provided in ESM Table S5.

\section{Results}

\section{Lithologies}

Representative lithologies and mineralization are illustrated in Fig. 2. These comprise Donington Suite granites, felsic and mafic (sub)volcanic rocks, siliceous (up to $80 \mathrm{wt} \%$ $\mathrm{SiO}_{2}$ ), K-feldspar-rich (up to $7.5 \mathrm{wt} \% \mathrm{~K}_{2} \mathrm{O}$ ) rocks (in IDD8; ESM Table S2), various rhythmically banded lithologies, and rocks with pervasive alteration typical of metasomatism. We consider the siliceous, K-feldspar-rich lithologies as arkose for the purpose of this contribution, although we cannot rule out a volcano-sedimentary origin. This choice of terminology is based on the fact that the volcano-sedimentary sequences from the Wallaroo Group, unlike those further south in the province (Moonta area: Conor et al. 2010), lack regional potassic alteration in the Olympic Dam district.
In all these, iron-oxides are important components, either within bands or as cm-sized pockets and veinlets, as well as throughout brecciated intervals. Donington Suite granites (e.g., in drillhole IDD3) are recognizable by the presence of K-feldspar megacrysts (Fig. 2A) and their foliated, sheared appearance (Fig. 2B), particularly when located close to, or within faults. Felsic volcanic rocks (Fig. 2C) are present as intervals within the arkose. The latter are the dominant lithologies intersected in drillholes IDD2, $-7,-8$, and -10 . Fine-grained, dark green mafic subvolcanic rocks occur as thin, m-sized intervals; these are interpreted as either sills or dikes.

Both the arkose and the banded lithologies represent distinctive packages within the Wallaroo Group. They display a wide variety of colors, pink to brown and green, and vary from fine- to coarser-grained varieties. Color variation is due to the presence of K-feldspar, disseminations of iron-oxides, and the presence of green minerals such as actinolite and phlogopite, as well as siderite and calcite. Actinolite and phlogopite are considered here as index minerals for those rocks defined as calcic exoskarn and magnesian endoskarn, respectively. Quartz and chlorite are present in variable proportions throughout any given rock. Ubiquitous ironoxides can form rhythmic banding with carbonates, chlorite and K-feldspar, as well as with skarn silicates. Among the lithologies enriched in iron-oxides are those forming rhythmically banded quartzitic intervals, in which K-feldspar is present either as porphyroblasts or as fine-grained bands (Fig. 2D, E). These are likely to represent Fe-rich metasedimentary rocks analogous to those of BIF type. Although skarn minerals are scarce or absent in such banded Fe-rich metasedimentary rocks (Fig. 2D, E), skarn silicates, with or without K-feldspar (Fig. 2F-H), represent major components of Si-poor, Mg-rich sediments (e.g., up to $13 \mathrm{wt} \% \mathrm{MgO}$ in IDD4). For simplicity, such lithologies are hereafter referred to as skarns.

Felsic volcanic intervals within volcanic-sedimentary sequences of the Wallaroo Group are interbedded with impure dolomites and can be considered as the $\mathrm{Mg}$-, $\mathrm{Ca}$-, K-bearing protoliths for skarn. This type of thinly interbedded protolith can explain the unusual fabrics observed, including the mottled green and pink (K-feldspar) appearance of some skarns (Fig. 2H), or the coarse-grained, $\mathrm{K}$-feldspar + calcite (+ quartz) intervals within banded skarn (Fig. 2I). In the latter, bundles of coarse-grained hematite are also present (Fig. 2I).

Characteristics for Island Dam skarns are carbonate-rich pockets and short veinlets containing lamellar hematite (Fig. 2J, K). Considering their fan-like arrangement and coarser size compared to minerals in host skarn, these hematite aggregates likely crystallized in open spaces (Fig. 2J). Copper-Fe-sulfides occur as disseminations and veinlets in 

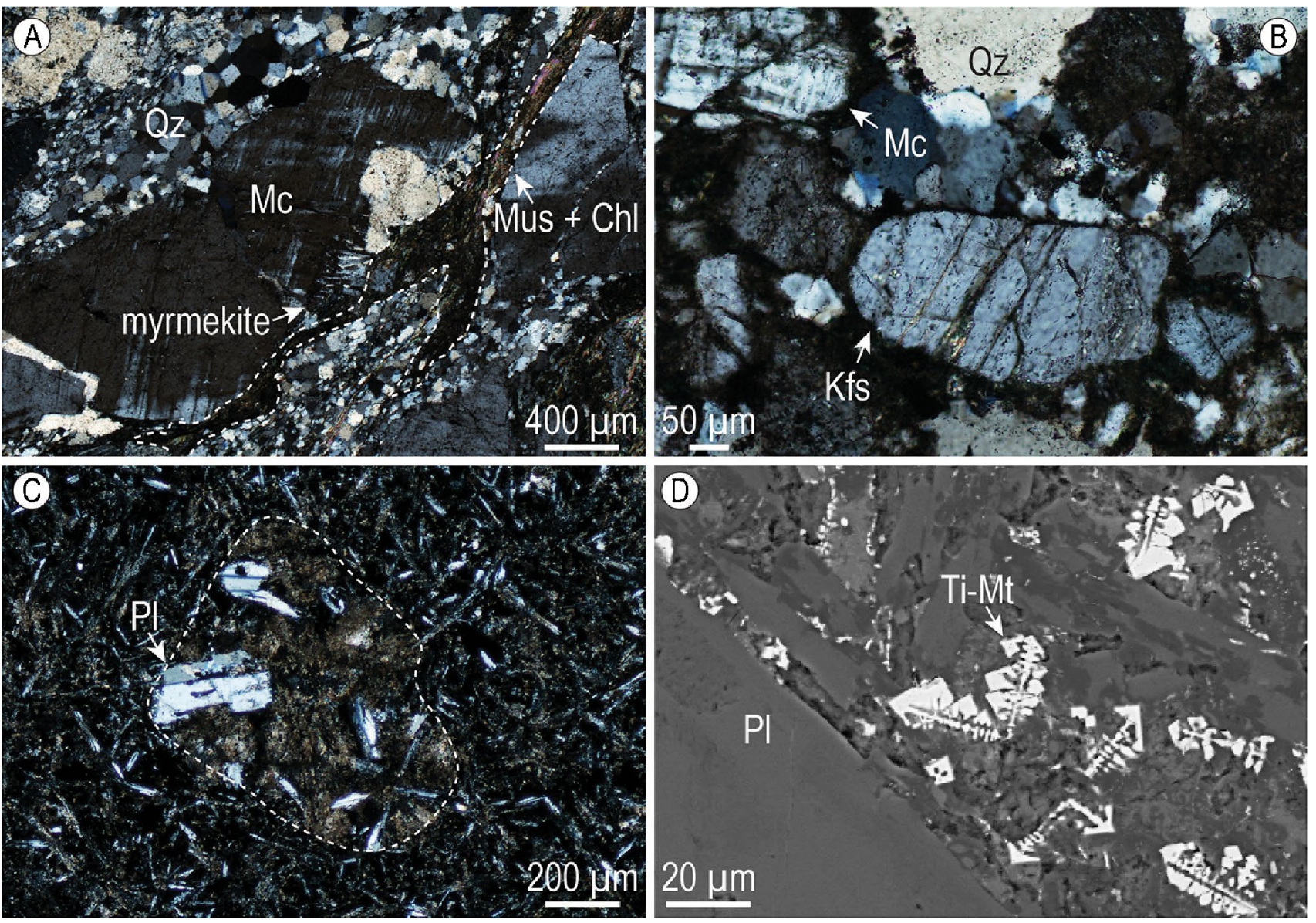

Fig. 4 (A-C) Cross-polarized optical and (D) BSE images showing representative features of igneous lithologies. (A) Development of quartz + plagioclase myrmekite and muscovite + chlorite foliation in megacrystic Donington Suite granite. (B) Rounded K-feldspar and microcline in felsic metavolcanic rock. (C) Aphanitic texture of mafic

skarn, in some cases within cm-wide barite-dominant veinlets (Fig. 2L).

\section{Deposit 3D geological modeling}

The lithological categories introduced above and the wholerock geochemical dataset for the 10 drillholes were used to produce a 3D geological model and define metal anomalies along two cross-sections (Fig. 3). The model was built by defining four lithological blocks demarcated by a series of sub-vertical faults. The AFZ offsets the arkose into northern and southern blocks, which are correlated across drillholes IDD7, -8, and -10 (Fig. 3; ESM Fig. S1). Secondary faults splay off the AFZ on the western margin of the prospect forming western and northwestern blocks. The western block comprises skarns (correlated across drillholes IDD1, $-4,-5,-6$, and -9; Fig. 3; ESM Fig. S1), which have been

dike showing pseudomorphic replacement of clinopyroxene or olivine by carbonate (dashed line) in a groundmass of plagioclase + titanomagnetite. (D) Skeletal titanomagnetite in mafic dike. Chl-chlorite; Mc-microcline; Mus-muscovite; $\mathrm{Pl}$-plagioclase; Qz-quartz; Ti-Mt - titanomagnetite

uplifted relative to the arkose and are also visible as an erosional window. The Donington Suite, intersected in drillhole IDD3, is exposed in the northwest of the prospect and is uplifted relative to neighboring blocks by normal faults on its southern and western margins (Fig. 3B). Mafic dikes and sills, displaced by faulting along the western margin of the prospect, are correlated across drillholes IDD3, -4 , and -10, with another sill intersected in IDD8 (ESM Fig. S1). An unconformable cover sequence of conglomerates, shales, and dolomites extends over the northern and western portions of the prospect.

Isolines for $\mathrm{Fe}, \mathrm{Cu}, \mathrm{Mo}, \mathrm{W}, \mathrm{Sn}$, and $\mathrm{U}$ (Fig. 3C) define metal distributions that highlight the association between the lithological categories and mineralization. Cross-section A-A' depicts the roughly sub-vertical faults between the Donington Suite, skarn and arkose, represented by drillholes IDD3, IDD9, and IDD7, respectively. Iron and 
$\mathrm{Cu}$ concentrations correlate in both skarn and arkose, however in the latter, increasing $\mathrm{Fe}$ (up to $30 \mathrm{wt} \%$ ) and $\mathrm{Cu}$ (up to $100 \mathrm{ppm}$ ) are coincident with increasing concentrations of Mo (up to $20 \mathrm{ppm}$ ), W (up to $75 \mathrm{ppm}$ ), and U (up to $15 \mathrm{ppm}$ ). In contrast, $\mathrm{Fe}$ and $\mathrm{Cu}$ concentrations in skarn are associated with elevated Sn (up to $10 \mathrm{ppm}$; cross-section B-B'). Uranium is associated with $\mathrm{Fe}$ in both skarn and arkose and reaches concentrations of up to $\sim 15 \mathrm{ppm}$ ).

\section{Petrography and mineral chemistry}

\section{Igneous rocks}

The Donington Suite granite preserves igneous K-feldspar phenocrysts (orthoclase and microcline), magnesiohornblende and, partially, biotite, whereas plagioclase is largely replaced by albite + sericite. Syn-orogenic deformation of K-feldspar phenocrysts is associated with formation of myrmekitic intergrowths between quartz and plagioclase (Fig. 4A). Replacement by later generations of feldspar is prominent along foliation defined by muscovite + chlorite and this becomes progressively evident in strongly sheared variants of the granite (Fig. 4A), where shears are marked by patches of anhedral, elongated K-feldspar + phlogopite. More melanocratic granites have a foliation defined by magnesiohornblende + phlogopite + K-feldspar. Although variably replaced, magmatic accessories preserved within the granites include Fe-Ti oxides, zircon, and apatite. Secondary apatite is a common phase that forms along domains of foliation and shearing. The felsic metavolcanic rocks are similarly composed of K-feldspar, microcline, and quartz and contain accessory phases such as zircon and apatite (Fig. 4B). The mafic dikes display aphanitic textures with carbonate pseudomorphs, after clinopyroxene or olivine phenocrysts (Fig. 4C), and plagioclase within a groundmass of finer-grained plagioclase and titanomagnetite (up to $27 \mathrm{wt} \%$ $\mathrm{TiO}_{2}$; ESM Table S6a). The latter display skeletal features (Fig. 4D).

\section{Skarns}

Skarns are characterized by the presence of amphibole and/ or biotite ( $\pm \mathrm{K}$-feldspar), magnetite, and quartz (Fig. 5A, B). Amphibole displays variable morphologies, from euhedral to acicular, and shows compositional variability expressed as core-to-rim or patchy zoning (Fig. 5C). Amphibole cores have compositions corresponding to either magnesiohornblende or an Fe-richer actinolite $[\mathrm{Mg} /$ $\left.\left(\mathrm{Mg}+\mathrm{Fe}^{2+}\right)=0.52-0.91\right]$, whereas rims are a $\mathrm{Mg}$-richer actinolite (Fig. 5D; ESM Table S6b). Although dark micas display Fe-richer and -poorer compositions (Fig. 5E), they are nonetheless $\mathrm{Mg}$-dominant and thus classified as phlogopite (Fig. 5F; ESM Table S6c). Arkose is composed of K-feldspar, quartz, and to a lesser degree, carbonates and sericite. Barium zoning within K-feldspar is common to all metasedimentary rocks. In exceptional cases, compositional variability in K-feldspar can be expressed as oscillatory zoning (Fig. 5G), in which $\mathrm{BaO}$ may attain concentrations as high as $2.5 \mathrm{wt} \%$ (Fig. 5H; ESM Table S6d).

A characteristic feature of skarns is the presence of both magnetite and hematite. Euhedral magnetite, which can occur as a matrix component, disseminated along bands or as intergrowths with silicate minerals (e.g., Fig. 5A, B), is Si-bearing (up to $2.7 \mathrm{wt} \% \mathrm{SiO}_{2}$; ESM Table S6a) at the $\mu \mathrm{m}$-scale and can be defined as 'silician magnetite.' Magnetite displays compositional zoning with $\mathrm{Fe}$-rich cores and Si-rich rims, with oscillatory zoning with respect to $\mathrm{Si}$ (Fig. 6A). Although magnetite is variably pseudomorphically replaced by hematite (martitization) (Fig. 6B), it can also display complex equilibrium relationships with coarsegrained lamellar hematite (Figs. 6C, 10B). Lamellar hematite displays compositional variability between cores and margins (Fig. 6C), or oscillatory or patchy zoning features visible on BSE images (Fig. 6D). Hematite within arkose and the Fe-rich horizons is characterized by acicular morphologies within polygranular hematite (Fig. 6E, F). Relict magnetite occurs within both the acicular and polygranular hematite (Fig. 6F). The polygranular hematite is generally Si-rich (Fig. 6G), whereas acicular hematite (and relict magnetite inclusions) contains dusty inclusions of scheelite (Fig. 6H).

Accessory minerals are abundant in the skarns. Zoned tourmaline, more common among the phlogopite skarns, displays bluish cores and green rims in transmitted light (Fig. 7A), corresponding to brighter (Fe-rich) and darker (Mg-rich) intensities, respectively, in BSE images (Fig. 7B). Fluorapatite, without any apparent compositional zoning, is present throughout all lithologies and displays an intimate relationship with silician magnetite (Fig. 7C), or with K-feldspar within more siliceous lithologies. Lozengeshaped pseudomorphs, more common within actinolite skarns, are evidence of pre-existing titanite (Fig. 7D). Assemblages resulting from replacement of titanite include fine-grained intergrowths of Fe-Ti oxides (Fig. 7E), which may harbor magmatic accessories such as zircon (Fig. 7F), or rutile + chlorite + calcite (Fig. 7G), that may have formed contemporaneous with martitization of silician magnetite. Rutile associated with lamellar hematite displays zoning with respect to tungsten and contains fine-grained inclusions of scheelite (Fig. 7H). Carbonates and fluorite are common within veins and within accumulations of $\mathrm{Ca}-$ REE-phosphates and -fluorocarbonates such as apatite and bastnäsite (Fig. 7I); the latter is partially replaced by synchysite (Fig. 7J). Molybdenite is a less common accessory 

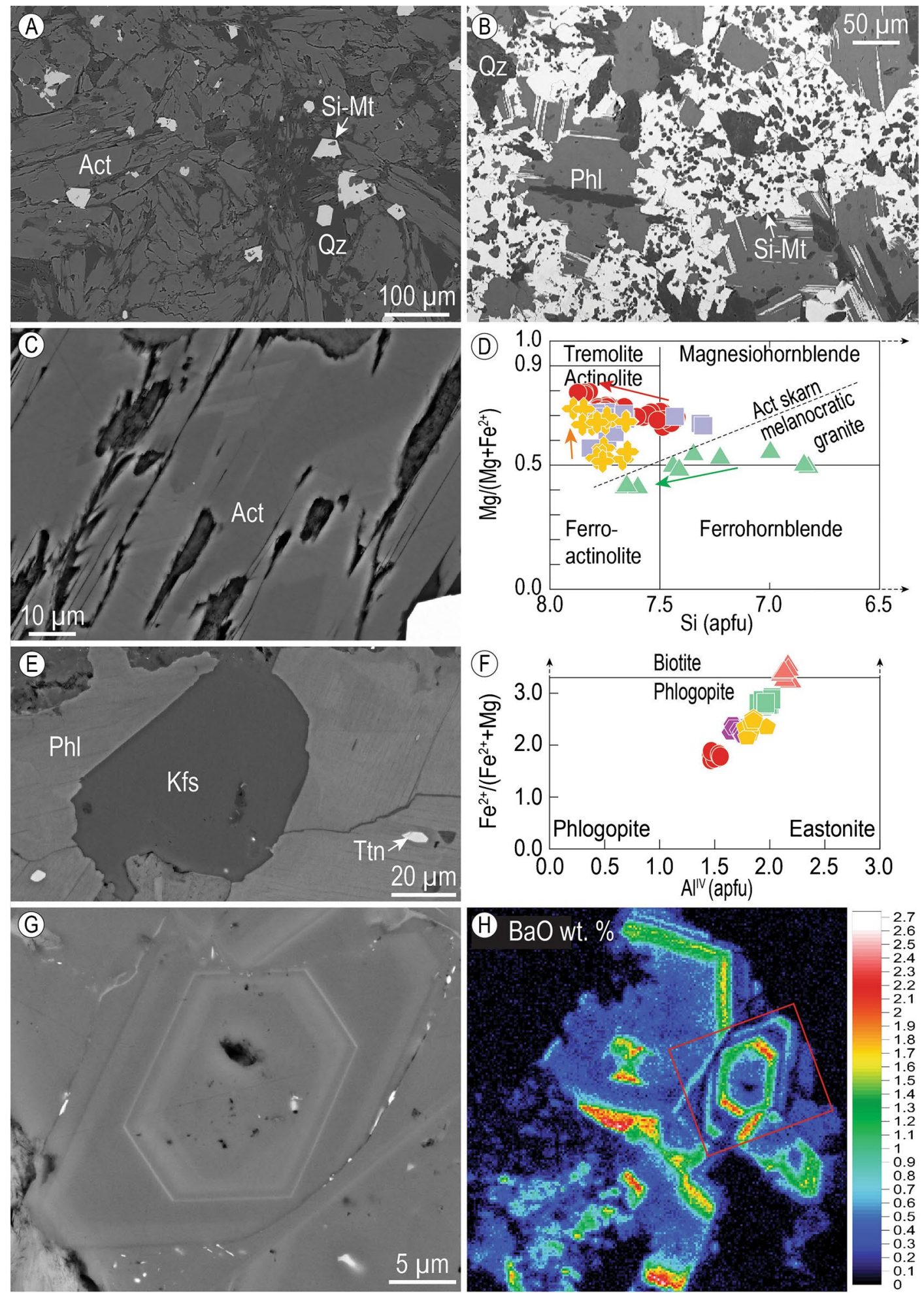

Fig. 5 BSE images showing representative features of skarn. Textures of (A) actinolite and (B) phlogopite skarns. Compositional variation in $(\mathbf{C}, \mathbf{D})$ amphibole and $(\mathbf{E}, \mathbf{F})$ biotite. Amphibole classification diagram after Leake et al. (1997). (G) Oscillatory Ba-zoning in
K-feldspar. (H) EPMA element map of K-feldspar grain from $(\mathbf{G})$ showing $\mathrm{BaO}$ (wt\%) concentration. Act - actinolite; Kfs - K-feldspar; $\mathrm{Phl}$-phlogopite; Qz-quartz; Si-Mt-silician magnetite; Ttn - titanite 

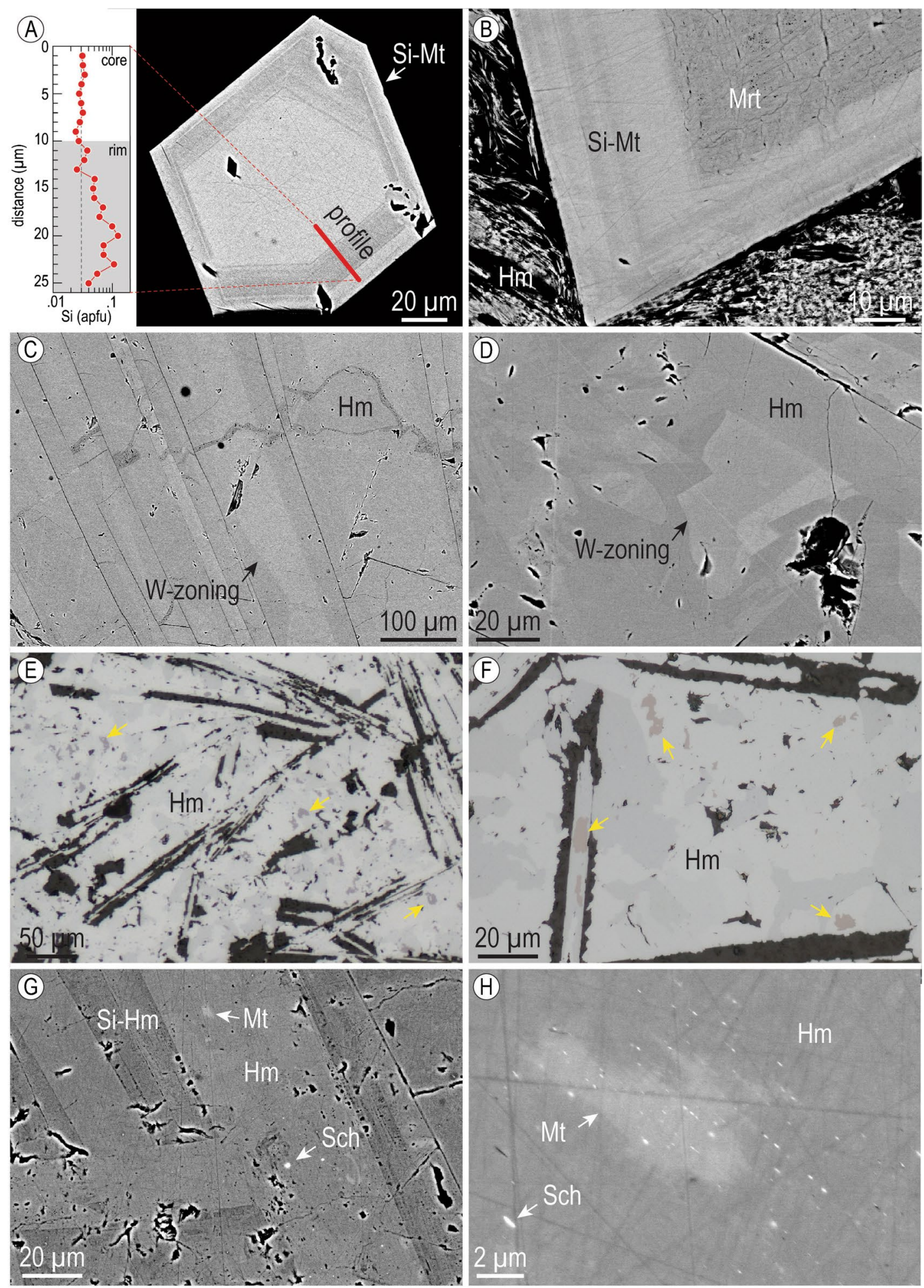

Fig. 6 (A-D, G, H) BSE and $(\mathbf{E}, \mathbf{F})$ reflected light images showing representative features of iron-oxides. (A, B) Oscillatory zoning in magnetite from skarn with profile (red line) showing $\mathrm{Si}$ variation. Lamellar hematite in skarn showing $(\mathbf{C})$ core to margin and (D) patchy W-zoning. (E, F) Hematite within arkose showing acic- ular and polygranular textures, with $(\mathbf{G}) \mathrm{Si}$ enrichment in the latter. Note the magnetite inclusions (yellow arrows) in both textures. $(\mathbf{H})$ Relict magnetite in acicular hematite showing dusty scheelite inclusions. Hm-hematite; Mrt-martite; Mt-magnetite; Sch-scheelite; $\mathrm{Si}-\mathrm{Hm}$ - silician hematite; Si-Mt - silician magnetite 


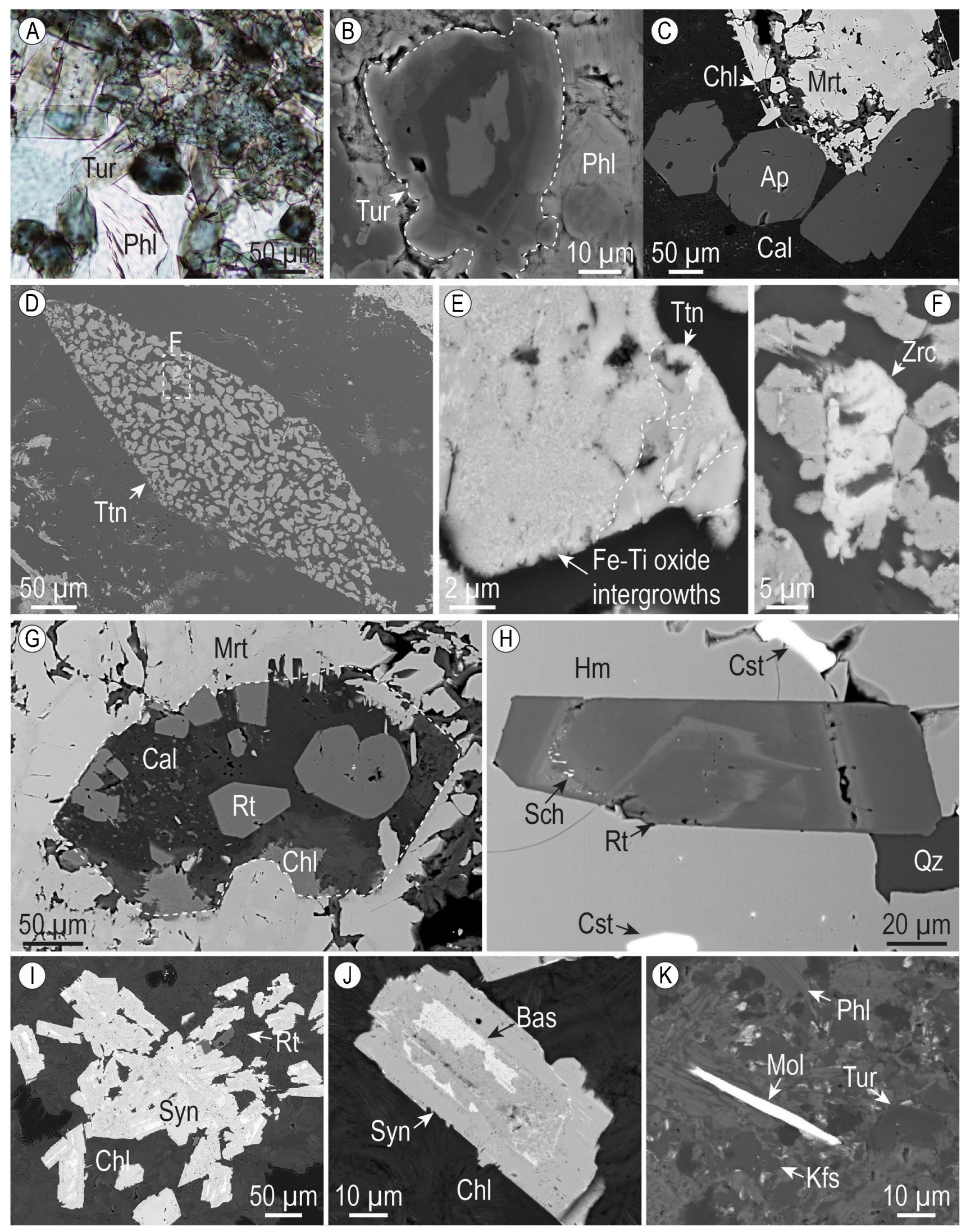


4Fig. 7 (A) Optical and (B-K) BSE images of accessory minerals within skarn. (A, B) Compositional zoning in tourmaline from $\mathrm{Fe}$-richer cores (blue) to $\mathrm{Mg}$-rich rims (green). (C) Fluorapatite associated with silician magnetite undergoing martitization. (D, E) Pseudomorphic replacement of titanite by aggregates of $\mathrm{Fe}-\mathrm{Ti}$ oxide intergrowths. (F) Relict zircon included in titanite pseudomorph. (G) Rutile + calcite pseudomorphic replacement of titanite. (H) Rutile associated with lamellar hematite showing W-zoning and scheelite inclusions. (I, J) Bastnäsite within veins showing synchysite replacement. (K) Molybdenite associated with phlogopite, $\mathrm{K}$-feldspar, and tourmaline. Ap-apatite; Bas-bastnäsite; Cal-calcite; Chl-chlorite; Cst - cassiterite; Kfs - K-feldspar; Mol-molybdenite; Mrt-martite; Phl-phlogopite; Rt-rutile; Sch-scheelite; Syn-synchysite; Tur - tourmaline

but is observed within phlogopite-K-feldspar assemblages (Fig. 7K).

\section{Mineralization}

Sulfide mineralization comprises chalcopyrite, pyrite, bornite, and less abundant sphalerite, galena, chalcocite, and molybdenite, within a gangue assemblage of hematite, chlorite, carbonates, fluorite, barite, and quartz. Sulfides occur as disseminations, within veins and as replacements of preexisting skarn minerals. Chalcopyrite is commonly associated with lamellar hematite, generally within pockets and veins (Fig. 2J, K), but can also occur as selective replacement of skarn assemblages along banding (Fig. 8A, B). Copper-Fe-sulfide species may co-exist (chalcopyrite and bornite; Fig. 8C), with exsolution of bornite in chalcopyrite observed (Fig. 8D). Symplectitic intergrowths between chalcopyrite and $\mathrm{Pb}$ - and $\mathrm{Ag}$-Bi-selenides, clausthalite $(\mathrm{PbSe})$ and bohdanowiczite $\left(\mathrm{AgBiSe}_{2}\right)$, further highlight the complexity of the ore mineral assemblages (Fig. 8E$\mathrm{H})$. These selenides occur as fields of dusty inclusions or rod-like lamellae within chalcopyrite (Fig. 8F) but also as two-component inclusions (Fig. 8G, H). Molybdenite occurs as discrete bundles tied to phlogopite-bearing assemblages (Fgs. 7K and 8I). Within mafic dikes, assemblages of pyrite, chalcocite, galena and sphalerite are associated with breakdown of Fe-Ti oxides (Fig. 8J).

\section{Trace element geochemistry}

Trace element concentrations were measured in iron-oxides, and in rutile, actinolite, and apatite from representative samples. Data for the three main types of iron-oxides (silician magnetite, coarse-grained lamellar hematite, and polygranular hematite) are illustrated in boxplots (Fig. 9A), selected bi-plots (Fig. 9B-D), and on LA-ICP-MS trace element maps (Fig. 10A, D). The trace elements presented in boxplots are grouped into 'granitophile elements' (W, Sn, Mo, $\mathrm{Th}$, and $\mathrm{U}$ ), high field strength elements ( $\mathrm{Ti}, \mathrm{Sc}, \mathrm{Zr}, \mathrm{Nb}$, and $\mathrm{Ta}$ ), chalcophile elements (As, $\mathrm{Sb}, \mathrm{Cu}, \mathrm{Zn}$, and $\mathrm{Ga}$ ), transitional metals ( $\mathrm{Mn}, \mathrm{V}, \mathrm{Cr}, \mathrm{Co}$, and $\mathrm{Ni}$ ), and lithophile elements ( $\mathrm{Mg}, \mathrm{Al}, \mathrm{Si}$, and $\mathrm{Ca})$. Trace element data for rutile, actinolite, and apatite are presented as binary-plots and REY fractionation patterns normalized to chondrite following McDonough and Sun (1995). Full trace element datasets are compiled in ESM Table S7a-e.

\section{Iron-oxides}

The presence of granitophile elements within the iron-oxides is a feature of both lamellar and polygranular hematite (Fig. 9A), and is readily seen on W, Sn and U LA-ICP-MS element maps for lamellar hematite (Fig. 10). Both types of hematite contain mean $\mathrm{W}$ concentrations in the hundreds to thousands of ppm, although this can vary between individual zones. However, only in lamellar hematite does W correlate with high Sn concentrations (mean $>100$ ppm; Fig. 9B). Tin is also present in polygranular hematite at concentrations up to $10 \mathrm{ppm}$. Molybdenum and $\mathrm{U}$ concentrations are highest in polygranular hematite with means of $\sim 5$ and $\sim 4 \mathrm{ppm}$, respectively.

All iron-oxide categories contain relatively high mean concentrations of $\mathrm{Ti}(\sim 200 \mathrm{ppm})$. Scandium and $\mathrm{Nb}$ are also markedly enriched in lamellar hematite (mean 16 and $35 \mathrm{ppm}$, respectively), with Sc reaching mean concentrations up to $150 \mathrm{ppm}$ in selected samples. Zirconium and Ta occur at concentrations $<1 \mathrm{ppm}$. Arsenic and $\mathrm{Sb}$ concentrations correlate strongly in all iron-oxides (Fig. 9C) but are highest in polygranular hematite (mean 30 and $6 \mathrm{ppm}$, respectively) and $<5$ ppm in both silician magnetite and lamellar hematite. Copper concentrations are $<1 \mathrm{ppm}$ in all iron-oxide subtypes. Zinc reaches $54 \mathrm{ppm}$ in silician magnetite and $13 \mathrm{ppm}$ in polygranular hematite, but only 2 ppm in lamellar hematite. Although measurable, mean $\Sigma$ REY concentrations in all iron-oxides are low $(<1.5 \mathrm{ppm})$; their chondrite-normalized REY fractionation trends are scattered and inconsistent.

Silician magnetite displays the greatest enrichment in transitional metals and lithophile elements compared to lamellar and polygranular hematite $(\mathrm{V}$ and $\mathrm{Ni}$, see Fig. 10D). Silician magnetite contains thousands of ppm $\mathrm{Mg}, \mathrm{Al}, \mathrm{Si}$, and $\mathrm{Ca}$, hundreds of ppm $\mathrm{Mn}, \mathrm{Zn}$, and $\mathrm{V}$, and tens of ppm Cr, Co, and Ni. Both hematite sub-types host $\mathrm{Mn}$ and $\mathrm{V}$ at tens and hundreds of ppm, respectively. The highest mean $\mathrm{Ni}$ concentrations $(\sim 33 \mathrm{ppm})$ were measured in polygranular hematite. Although $\mathrm{Co}$ and $\mathrm{Ni}$ concentrations are lowest in lamellar hematite, this textural sub-type shows the strongest correlation between the two elements (Fig. 9D). Magnesium, Al, Si, and $\mathrm{Ca}$ were all measured within the two hematite textures at concentrations in the tens and hundreds of ppm range, $\sim 1-2$ orders of magnitude less than in silician magnetite. 

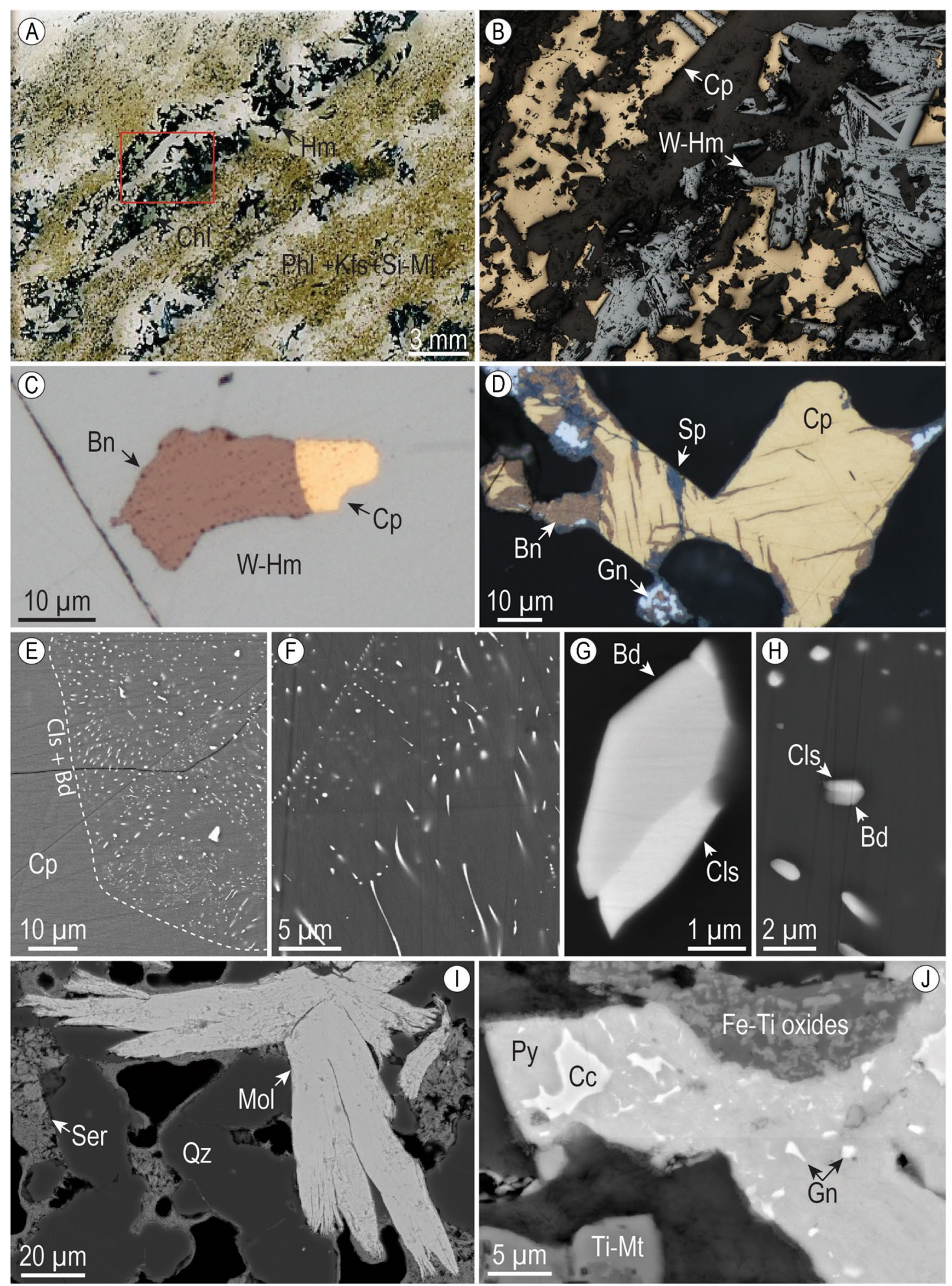

Fig. 8 (A) Scanned image of thin-section and (B-D) reflected light and (E-J) BSE images of sulfide minerals. (A, B) Chalcopyrite + lamellar hematite intergrowths occurring as selective replacement along banding in skarn. (C) Chalcopyrite + bornite intergrowth within lamellar hematite. (D) Bornite exsolution within chalcopyrite with associated galena and sphalerite. (E-H) Symplectic intergrowths between chalcopyrite, clausthalite, and bohdanowiczite. (I) Molyb- denite bundle. (J) Pyrite, chalcocite, galena, and sphalerite associated with breakdown of $\mathrm{Fe}$-Ti oxides in mafic dike. $\mathrm{Bd}-$ bohdanowiczite; $\mathrm{Bn}$ - bornite; $\mathrm{Cc}$ - chalcocite; $\mathrm{Chl}$ - chlorite; $\mathrm{Cls}$ - clausthalite; $\mathrm{Cp}$-chalcopyrite; $\mathrm{Gn}$-galena; $\mathrm{Hm}$-hematite; Kfs-K-feldspar; Mol-molybdenite; Phl-phlogopite; Py-pyrite; Ser-sericite; Si-Mt - silician magnetite; $\mathrm{Sp}$ - sphalerite; Ti-Mt --titanomagnetite 

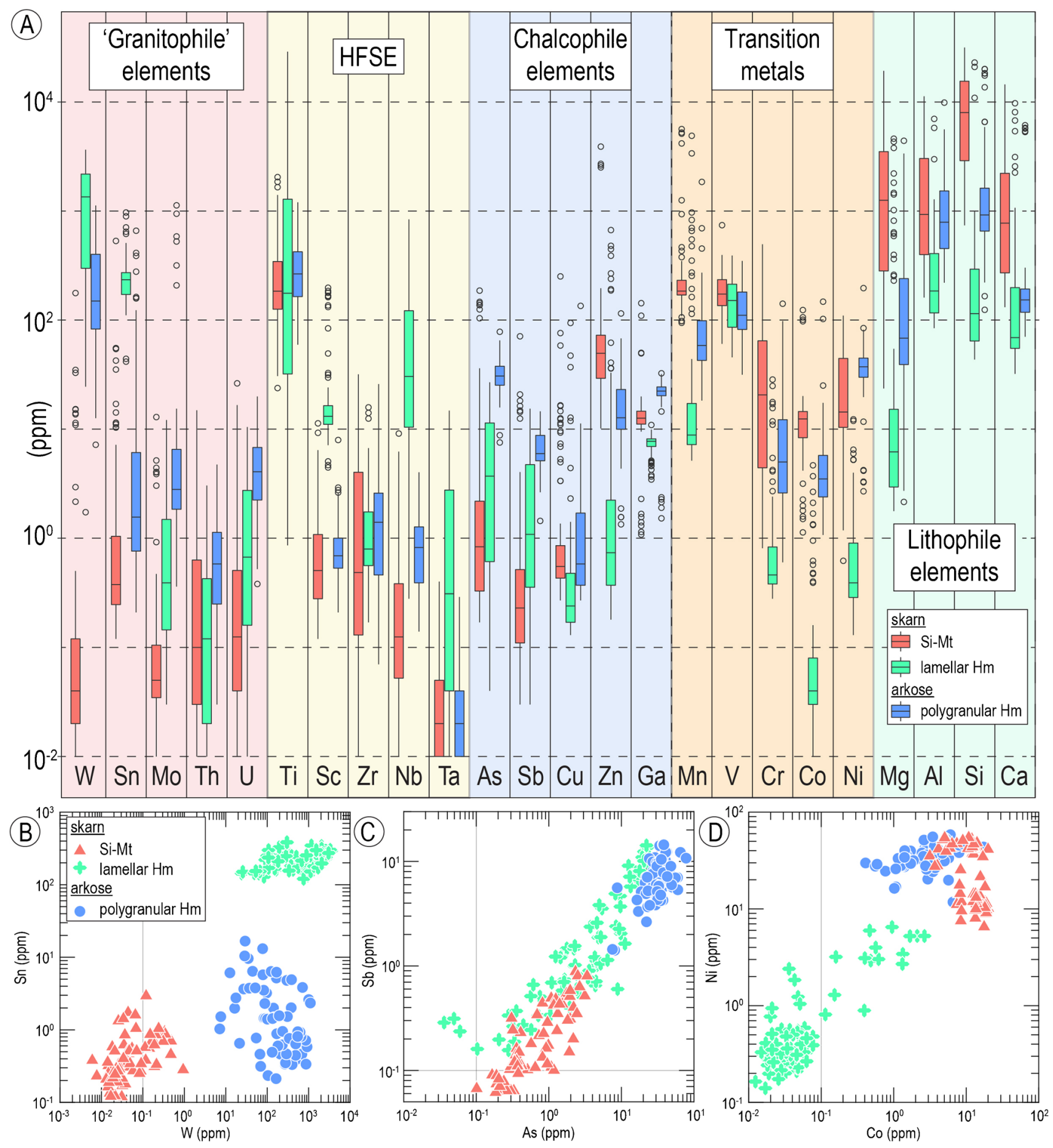

Fig. 9 LA-ICP-MS trace element concentration data for iron-oxides from skarn and arkose presented as (A) box plots, showing ranges for groups of elements as indicated, and binary plots for (B) W vs. $\mathrm{Sn}$, (C) As vs. Sb and (D) Co vs. Ni. Hm-hematite; Si-Mt-silician

\section{Rutile, actinolite, and apatite}

Trace elements were analyzed in two distinct textural types of rutile: rutile replacing titanite (Rt1, Fig. 7G); and zoned magnetite. 'Granitophile' group elements consists of those considered to have affinity with the host granite at Olympic Dam (Verdugo-Ihl et al. 2017) whereas other element groups are defined according to general chemical principles

rutile associated with lamellar hematite (Rt2; Fig. 7H). The two types contain comparable Sn $(\sim 675 \mathrm{ppm}), \mathrm{U}(\mathrm{Rt} 1=37$, Rt2 $=40 \mathrm{ppm})$ and similar mean concentrations of Sc, Zn, As, and $\mathrm{Sb}(7-20 \mathrm{ppm})$. Rt2 is significantly enriched in 

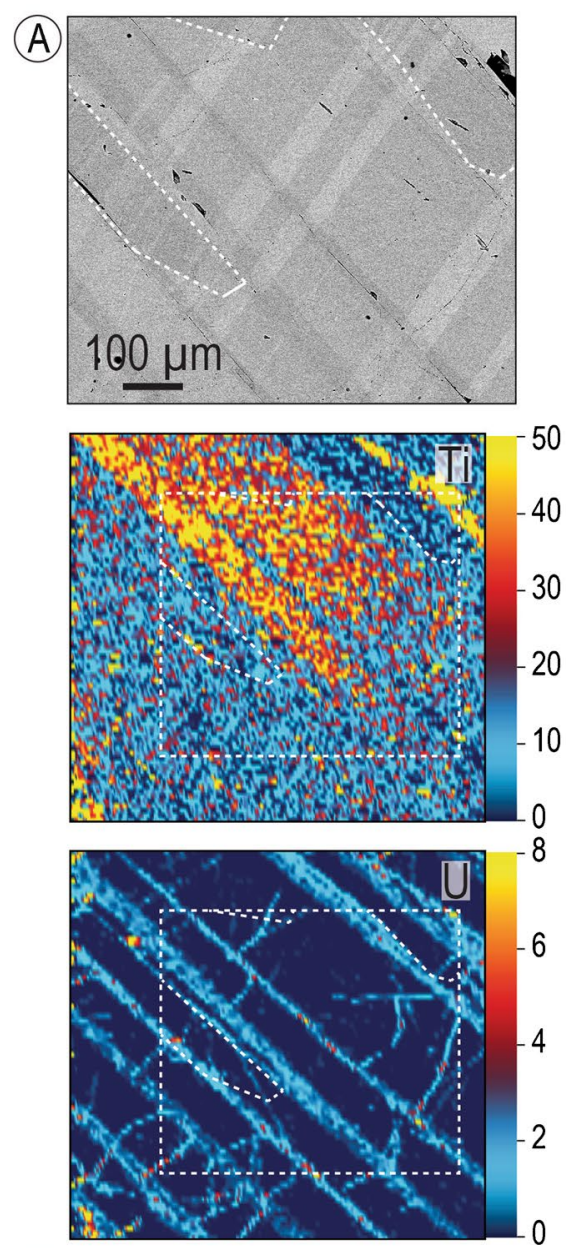

(B)

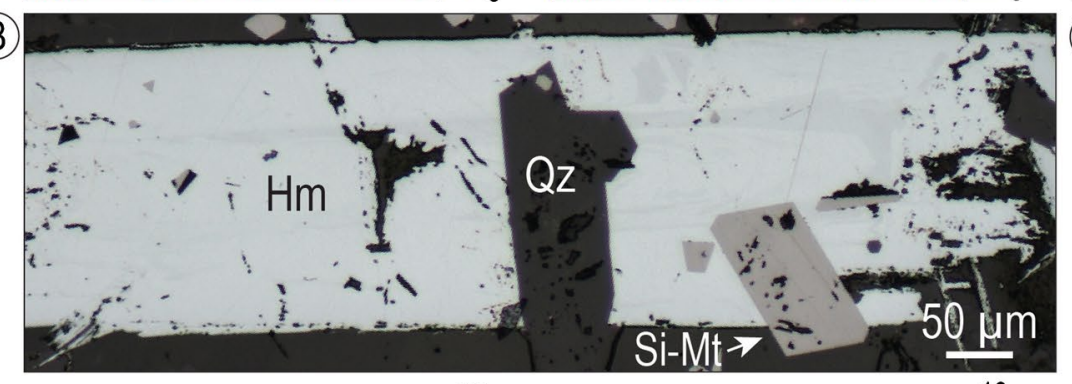

(D)
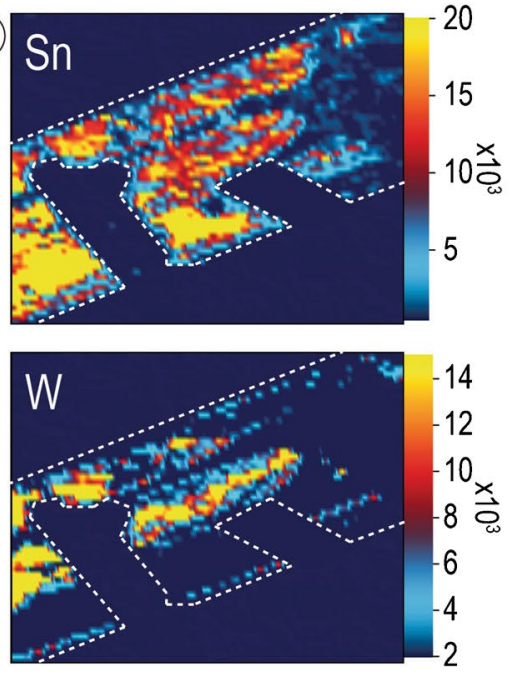
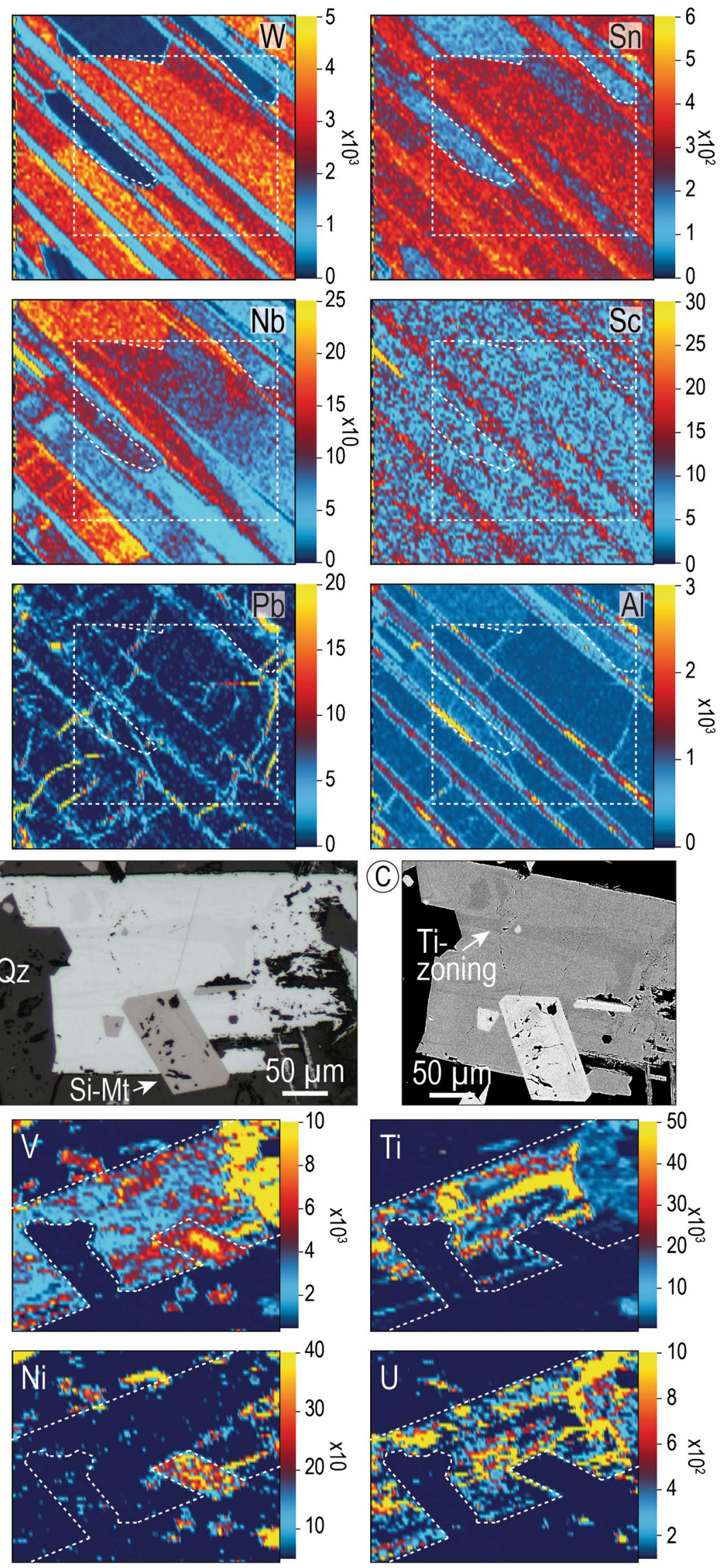
4Fig. 10 LA-ICP-MS trace element maps of iron-oxides in skarn. (A) Enrichment of granitophile elements, HFSE, and Al in lamellar hematite, shown in Fig. 2J. Mapped area shown on BSE image on top left and represented by a dashed rectangle on element maps. Note the visible twinning (brighter on BSE image) crosscutting the zoning (on chemical maps). The $\mathrm{W}$ and $\mathrm{Sn}$ zoning is along the elongation of lamellae or the $c$ axis of hematite. Some lamellae display domain zoning across the elongation with respect to $\mathrm{W}, \mathrm{Sn}$ versus $\mathrm{Nb}$ and Ti. Areas between lamellae, porous and darker on BSE images, are relatively enriched in $\mathrm{Sc}, \mathrm{U}, \mathrm{Pb}$, or $\mathrm{Al}$. Incipient brecciation (visible on the $\mathrm{U}$ and $\mathrm{Pb}$ maps) crosscutting the lamellae correlates with the twinning direction indicating these are likely of mechanical type. Reflected light (B) and BSE (C) images showing the relationship between lamellar hematite and silician magnetite and (D) LAICP-MS trace element maps showing relative enrichments in the elements indicated. Element scales in ppm. Hm - hematite; Qz - quartz; Si-Mt - silician magnetite

W ( 20,000 ppm) relative to Rt1 ( 48 ppm) (Fig. 11A), whereas Rt1 has higher Zr and Hf (1800 and 63 ppm, respectively) relative to Rt2 (43 and $7 \mathrm{ppm}$, respectively). Strong correlations between the two elements are seen in both types (Fig. 11B). Chromium is also enriched in Rt1 (399 ppm) compared to Rt2 (18 ppm) (Fig. 11C), and Rt2 contains higher V (1,680 ppm), Nb (11,355 ppm) and Ta (550 ppm) relative to Rt1. Rt1 has a higher mean $\Sigma$ REY (126 ppm) than Rt2 (30 ppm) with a chondrite-normalized REY fractionation trend that slopes slightly upwards, whereas that of Rt2 is relatively flat. Both types of rutile display weak negative Eu- and Y-anomalies (Fig. 11D).

Actinolite within the studied samples contains high mean concentrations of Ti ( $320 \mathrm{ppm}), \mathrm{V}(\sim 35 \mathrm{ppm})$, Co $(\sim 10 \mathrm{ppm})$, and $\mathrm{Ni}(>10 \mathrm{ppm} \mathrm{ppm})$. Zinc is also enriched in actinolite ( $\sim 00 \mathrm{ppm})$, as is $\mathrm{Zr}(>5 \mathrm{ppm})$, and $\mathrm{Sn}(>6 \mathrm{ppm})$. Actinolite contains high average $\Sigma$ REY of $\sim 17 \mathrm{ppm}$, with high Y ( 10 ppm) and chondrite-normalized REY fractionation patterns characterized by relative LREE depletion, HREE enrichment, and weak positive Y-anomalies (Fig. 11E).

Apatite contains similarly low concentrations of most trace elements, generally at concentrations below $5 \mathrm{ppm}$, although $\mathrm{Mn}$ and Fe are both consistently present at hundreds to thousands of ppm. With the exception of apatite from the megacrystic granite, hundreds of ppm As are present in all other samples as well as tens to hundreds of ppm $\mathrm{Sr}$ throughout the sample suite. Although U typically occurs at only low concentrations ( $<3 \mathrm{ppm})$, hydrothermal apatite within the megacrystic granite and a sheared equivalent both contained somewhat higher U (44 and $5.6 \mathrm{ppm}$, respectively). The average $\Sigma$ REY for apatite ranges from 520 to $3100 \mathrm{ppm}$, the highest occurring in hydrothermal apatite from the megacrystic granite. Apatite from skarns displays chondrite-normalized REY fractionation patterns that are LREE-enriched and HREE-depleted, although with change in slope, and prominent negative Eu-anomalies (Fig. 11F). Apatite from a felsic metavolcanic displays
MREE-enrichment with a negative Eu-anomaly (Fig. 11G). Magmatic apatite from a megacrystic granite displays a slight LREE-enrichment/HREE-depletion with a negative Eu-anomaly whereas hydrothermal apatite is characterized by a flat pattern but is relatively REY-enriched compared with other apatite (Fig. 11H). Apatite from a sheared granite has a LREE-enriched/HREE-depleted REY fractionation pattern with no anomalies, and apatite from a mylonite has a relatively flat pattern with a weak negative Y-anomaly (Fig. 11I).

\section{LA-ICP-MS U-Pb hematite and apatite geochronology}

Uranium-Pb LA-ICP-MS geochronology was performed on lamellar hematite within skarn (sample WK29) and hydrothermal apatite from megacrystic granite and a sheared variant. Hematite data is given as a ${ }^{207} \mathrm{~Pb} /{ }^{206} \mathrm{~Pb}$ weighted mean age and apatite data are given as $\mathrm{Pb}^{207}$-corrected weighted mean ${ }^{207} \mathrm{~Pb} /{ }^{206} \mathrm{~Pb}$ ages, with uncertainties for both minerals presented at the $2 \sigma$ level. The data are presented in Fig. 12 and complete datasets are provided in ESM Table S8a, b.

Thirty spot analyses were taken from $\mathrm{cm}$-scale hematite lamellae like that illustrated in Fig. 10B. These lamellae show compositional heterogeneity and concentrations of $\mathrm{U}$ ranging from 2.17 to $10.44 \mathrm{ppm}$ (mean $5.7 \mathrm{ppm}$ ), and Th from 0.46 to $3.04 \mathrm{ppm}$ (mean $1.5 \mathrm{ppm}$ ). The Tera-Wasserburg diagram (Fig. 12A) displays a spread from nearconcordant to highly discordant data resulting from mixtures or radiogenic and common- $\mathrm{Pb}$ components. Of the 30 analyses, 14 with low common- $\mathrm{Pb}$ cluster around concordia and were used to obtain a ${ }^{207} \mathrm{~Pb} /{ }^{206} \mathrm{~Pb}$ weighted mean age of $1594 \pm 28 \mathrm{Ma}(\mathrm{MSWD}=0.87$; Fig. 12B).

Euhedral hydrothermal apatite from megacrystic granite (WK 64) is inclusion-free and concentrated along the foliation defined by muscovite + chlorite (Fig. 12C). Eleven analyses were obtained. These have $\mathrm{U}$ concentrations from 20 to $63 \mathrm{ppm}$ (mean $44 \mathrm{ppm}$ ), and Th from 0.15 to $4.11 \mathrm{ppm}$ (mean $0.65 \mathrm{ppm}$ ). All analyses were included in the age calculation, yielding a ${ }^{207} \mathrm{~Pb}$-corrected ${ }^{207} \mathrm{~Pb} /{ }^{206} \mathrm{~Pb}$ weighted mean age of $1594 \pm 35 \mathrm{Ma}$, with a MSWD of 4.8 (Fig. 12D).

Apatite within the sheared granite (WK 61) forms anhedral patches throughout the sample (Fig. 12E), with some grains concentrated along shears. Although some apatite grains display clean, inclusion-free surfaces, many grains contained fine-grained inclusions of hematite, chlorite, and synchysite. Forty-five spot analyses were made on apatite, from which 24 were rejected due to high common- $\mathrm{Pb}$. The remaining twenty-one analyses had $\mathrm{U}$ concentrations from 1.73 to $10.30 \mathrm{ppm}$ (mean $5.57 \mathrm{ppm}$ ), and Th from 3.06 to $19.39 \mathrm{ppm}$ (mean $10.18 \mathrm{ppm}$ ) and yield a ${ }^{207} \mathrm{~Pb}$ corrected ${ }^{207} \mathrm{~Pb} /{ }^{206} \mathrm{~Pb}$ weighted mean age of $1575 \pm 35 \mathrm{Ma}$ $(\mathrm{MSWD}=2.2$; Fig. 12F). 

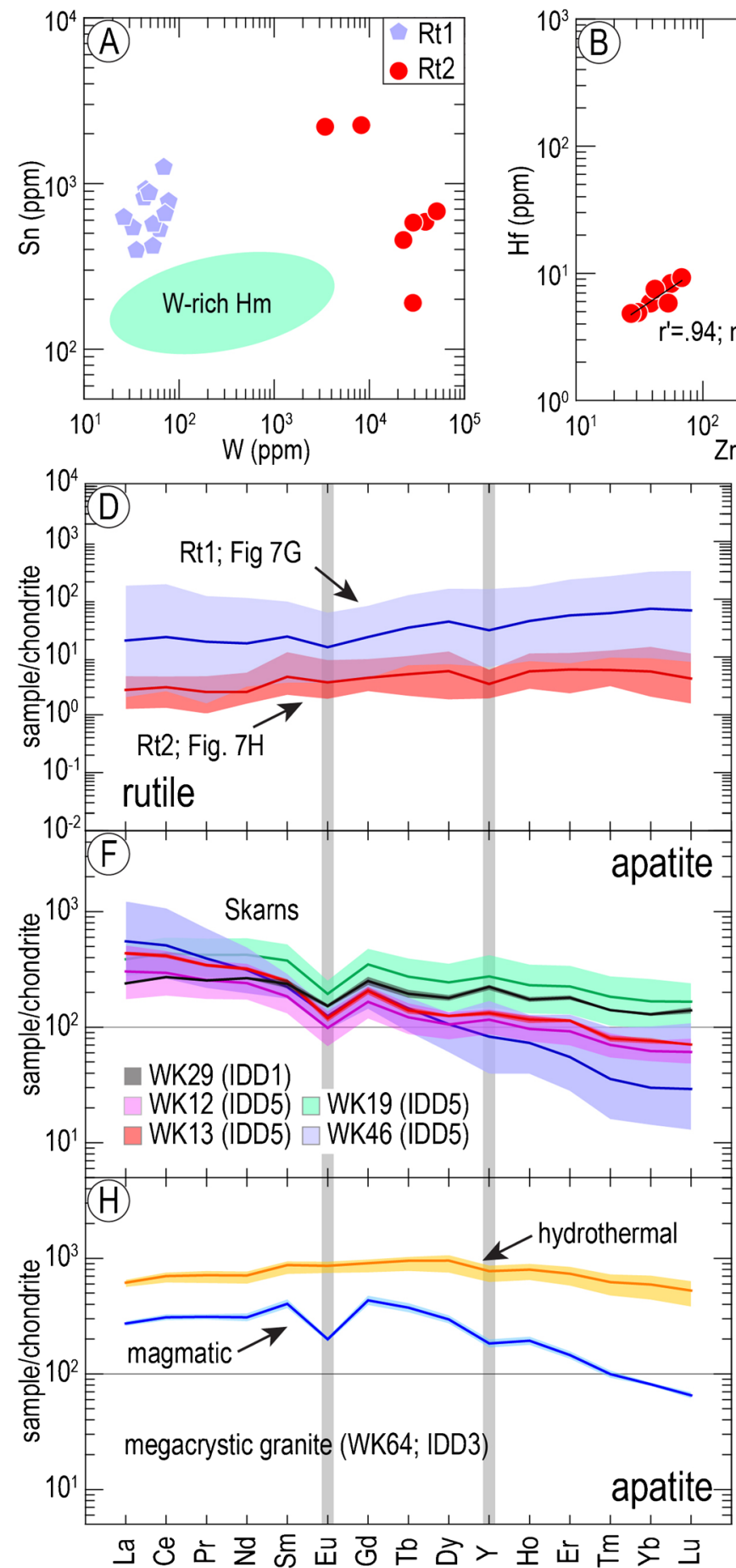

Fig. 11 (A-C) Binary plots for trace element concentrations in rutile from skarn pseudomorphically replacing titanite (Rt1; Fig. 7G) and rutile associated with lamellar hematite showing W-zoning (Rt2; Fig. 7H). (D-I) REY fractionation patterns for (D) rutile, (E) actinolite, and (F) apatite from skarn, and (G-I) apatite from igneous lith-
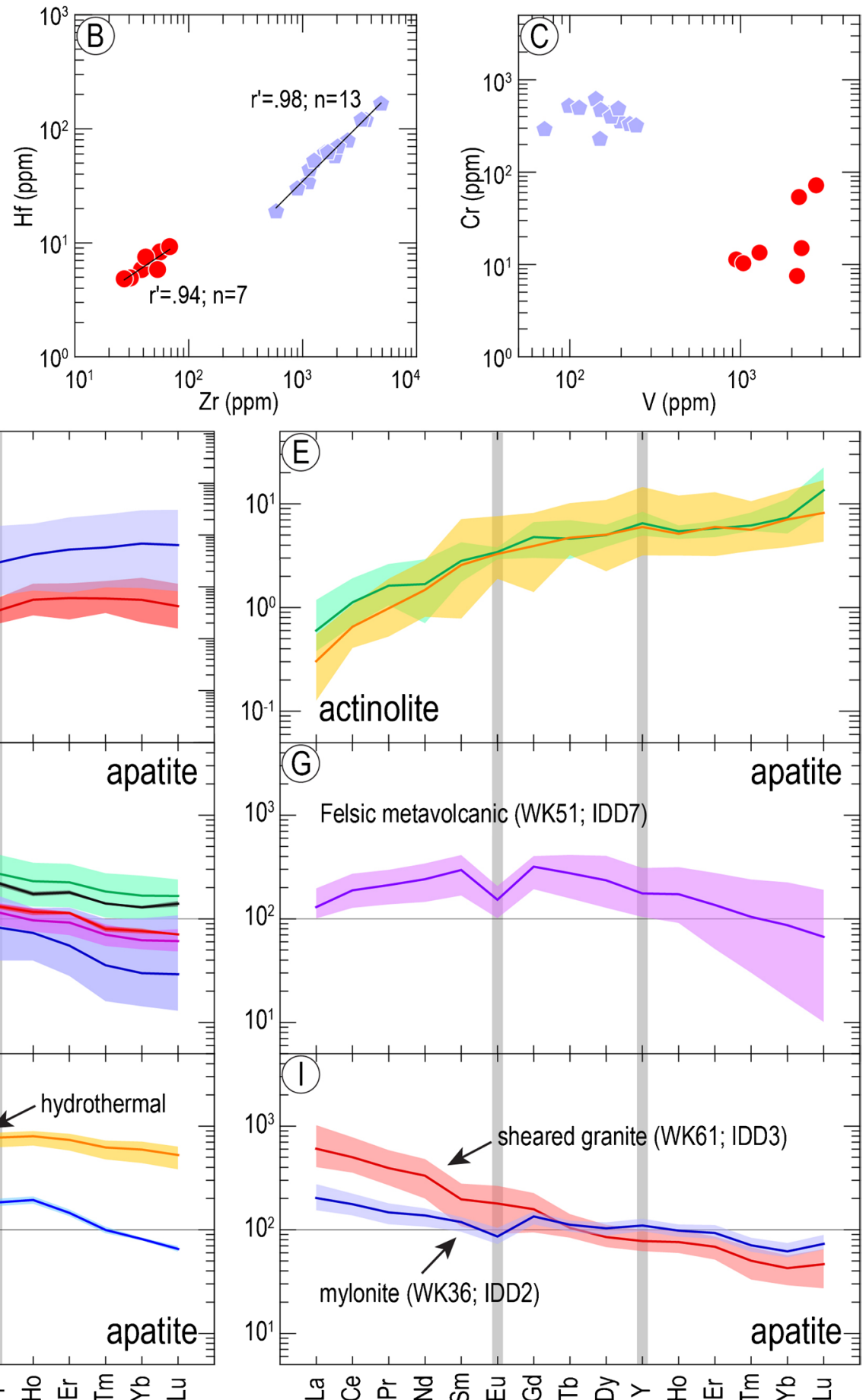

ologies normalized to chondrite after McDonough and Sun (1995). For REY fractionation patterns, thick colored lines represent sample average, while shaded fields represent compositional range. Note the difference between the patterns for magmatic and hydrothermal apatite from megacrystic granite in $(\mathbf{H})$ 


\section{Discussion}

\section{Protoliths for host lithologies at Island Dam}

The Wallaroo Group is an important lithostratigraphic host for IOCG alteration systems throughout the Olympic $\mathrm{Cu}-\mathrm{Au}$ Province (Skirrow et al. 2007; Reid and Fabris 2015). Although metasedimentary rocks at Island Dam have been correlated with the Wallaroo Group, they remain temporally unconstrained. Lamellar hematite within skarn, dated here at $1593 \pm 28 \mathrm{Ma}$, would therefore be $\sim 150$ Ma younger than the inferred host rocks. Epigenetic crystallization of the hematite is supported texturally by its coarse grain size, fan-like morphology and occurrence infilling pockets and vugs. The $1594 \pm 35 \mathrm{Ma}$ and $1575 \pm 35 \mathrm{Ma}$ ages obtained from apatite within foliations and shears in the $\sim 1860$ Ma Donington Suite granite samples postdate emplacement age of the host granite by $\sim 250 \mathrm{Ma}$. These geochronological results can thus be interpreted in terms of an overprinting mineralizationalteration event. The distinct REY fractionation patterns for apatite (Fig. 11) support different fluid origins (magmatic and hydrothermal).

Reid et al. (2011) correlated the metasedimentary protolith hosting $\mathrm{Cu}-\mathrm{Au}$ mineralization and skarn alteration at Punt Hill to the Wallaroo Group based on stratigraphic similarities such as fine sediment lamination, and from age constraints between $\sim 1845 \mathrm{Ma}$, the age of the underlying Donington Suite granite, and the timing of prograde skarn formation at $\sim 1580 \mathrm{Ma}$. A similar approach can be used to provide indirect age constraints on the metasedimentary protolith hosting skarn at Island Dam. The basement Donington Suite granite, intersected in drillhole IDD3 and dated at $1860 \pm 4 \mathrm{Ma}$ (Jagodzinski 2005), provides a lower age limit for deposition of the overlying sedimentary package while an upper age limit is represented by the $\sim 1590 \mathrm{Ma}$ overprinting event dated here. Taking the $\sim 1860-1590 \mathrm{Ma}$ age range together with lithological similarities (laminated and banded pink-green lithologies) and studies that confirm Wallaroo Group sequences over the entire extent of the Olympic $\mathrm{Cu}-\mathrm{Au}$ Province from the Mt. Woods Inlier in the north to the Yorke Peninsula in the south (Cowley et al. 2003), the metasedimentary host at Island Dam can also be considered as part of the $~ 1750$ Ma Wallaroo Group.

Further constraints on protoliths at Island Dam can be made based on the geochemical signatures of iron-oxides within rhythmically banded lithologies and arkose assigned to the Wallaroo Group. The textural and chemical characteristics of the silician magnetite in skarn described here can be attributed to an early alkali-calcic alteration event associated with onset of IOCG mineralization, analogous to silician magnetite within the weakly mineralized 'outer shell' at Olympic Dam (Ciobanu et al. 2019; Verdugo-Ihl et al. 2020) and at Wirrda Well (Ciobanu et al. 2022). Transition element signatures in magnetite (V-Ni-Co; Figs. 9 and 10) are also suggested to be a characteristic of early HT IOCG mineralization (Dmitrijeva et al. 2019). The distinct W-SnMo-U signatures within coarse-grained lamellar hematite and acicular and polygranular hematite can likewise be considered analogous to IOCG-associated alteration during the $\sim 1.6 \mathrm{Ga}$ Hiltaba event. The latter has been temporally constrained by $\mathrm{U}-\mathrm{Pb}$ dating of iron-oxides from Olympic Dam and other IOCG deposits in the region (Ciobanu et al. 2013; Courtney-Davies et al. 2019b, 2020a).

Although the lamellar hematite is clearly hydrothermal and dated here at $\sim 1590 \mathrm{Ma}$, the acicular and polygranular hematite are more difficult to interpret. These display magnetite inclusions indicative of complex iron-oxide interconversions that reflect superimposed fluid-rock interactions with a pre-existing iron-oxide-rich lithology. This hematite also shows relative enrichments in chalcophile elements (As, Sb), transitional metals (Co, Ni), Mo, and U (Fig. 9), quite distinct from the HFSE, W-Sn signature of lamellar hematite. These elements are, however, characteristic of hematite from most of the IOCG deposits/prospects in the region, either in iron-oxides (e.g., Olympic Dam; VerdugoIhl et al. 2017), or in skarn minerals (e.g., garnet from Hillside; Ismail et al. 2014). Uranium-rich magnetite from the margin of the Olympic Dam deposit displays sedimentary textures and is dated at $\sim 1760 \mathrm{Ma}$ (Courtney-Davies et al. 2020b). These data were used to support an interpretation in which the magnetite was derived from iron-rich horizons within the Wallaroo Group that became modestly enriched in U from fluids associated with 1760 Ma granites (Reid et al. 2013) prior to incorporation into the 'outer shell' of the Olympic Dam deposit during granite uplift. Similar genetic interpretations have been made for U-rich iron-oxides in metasedimentary basement rocks hosting $\mathrm{U}$ mineralization in the Kiggavik-Andrew Lake structural trend area, Nunavut, Canada, which also preserve the geochemical signatures of their magmatic predecessors (Makvandi et al. 2021). The hematite within arkose at Island Dam may likewise represent overprinted iron-rich horizons, with Mo-U signatures attributable to interaction with hydrothermal fluids associated with the $\sim 1.6 \mathrm{Ga}$ Hiltaba event, or potentially, with earlier 1760 Ma granites.

\section{Comparison of alteration at Island Dam with elsewhere in the Olympic Cu-Au Province}

Strong mineralogical similarities exist between the alteration recognized at Island Dam and deposits/prospects elsewhere in the Olympic $\mathrm{Cu}-\mathrm{Au}$ Province. Host rocks at the Hillside skarn deposit, Moonta-Wallaroo district are, for example, characterized by pink (K-feldspar)-green 

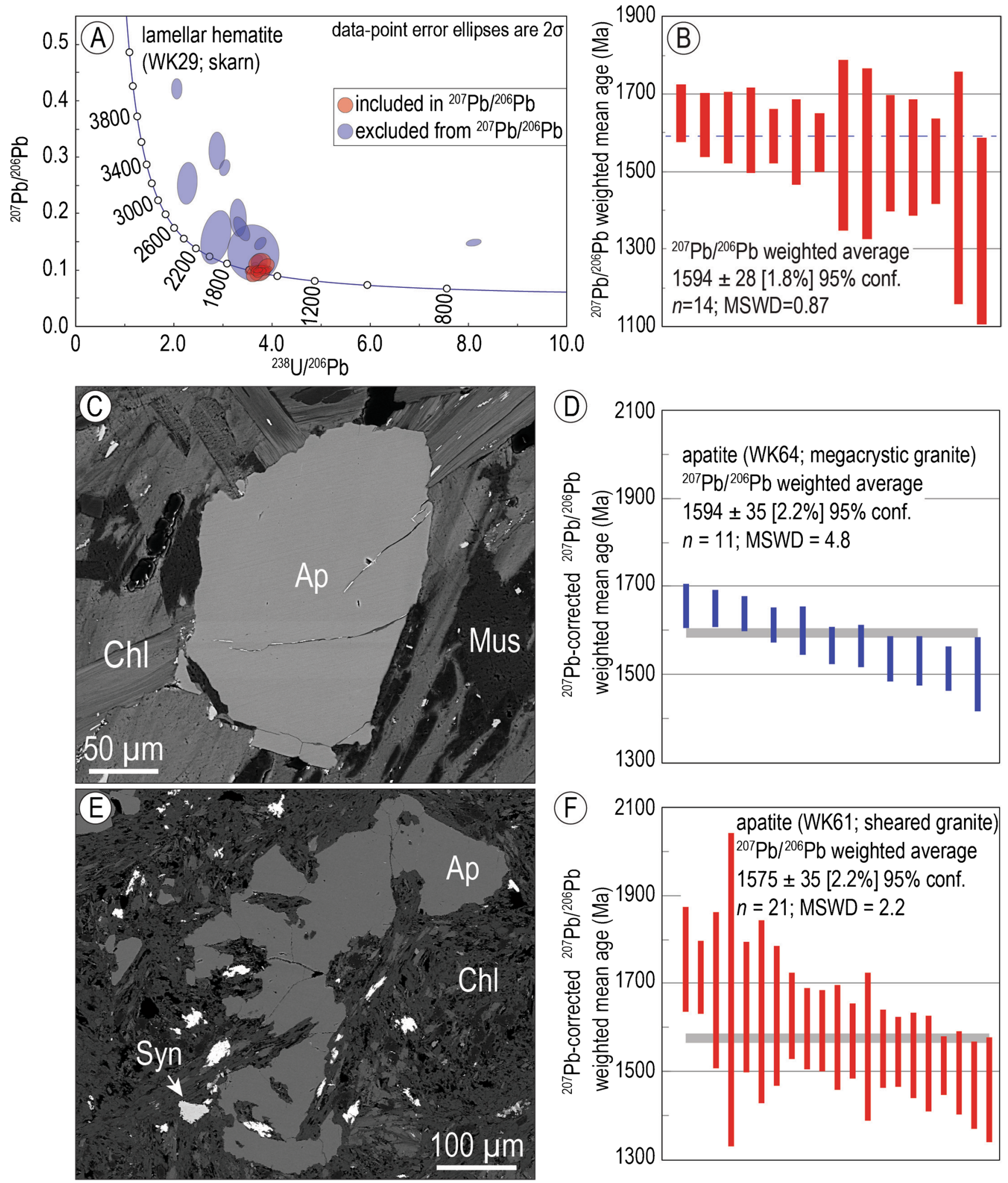

Fig. 12 (A) Tera-Wasserburg diagram and (B) corresponding ${ }^{207} \mathrm{~Pb} /{ }^{206} \mathrm{~Pb}$ weighted mean age diagram for lamellar hematite shown in Fig. 10B. (C) BSE image of hydrothermal apatite from megacrystic Donington Suite granite and (D) corresponding ${ }^{207} \mathrm{~Pb}$-corrected
${ }^{207} \mathrm{~Pb} /{ }^{206} \mathrm{~Pb}$ weighted mean age. (E) BSE image of hydrothermal apatite from sheared Donington Suite granite and (F) corresponding ${ }^{207} \mathrm{~Pb}$-corrected ${ }^{207} \mathrm{~Pb} /{ }^{206} \mathrm{~Pb}$ weighted mean age. Ap-apatite; Chlchlorite; Mus-muscovite; Syn-synchysite 
(epidote/actinolite) banded lithologies and lithologies resembling BIF ('red-rock') consisting of alternating layers of red K-feldspar and dark iron-oxides (Ismail et al. 2014), comparable with those at Island Dam. Such assemblages are interpreted as retrograde or distal skarns relative to preserved prograde garnet-pyroxene assemblages, also containing epidote-group minerals and K-feldspar. Laminated lithologies at Punt Hill also preserve prograde assemblages of grossular-rich garnet and diopside (Reid et al. 2011). Although widely variable, the retrograde assemblages at Punt Hill also contain actinolite, K-feldspar, and calcite, but also garnet and hedenbergite. Early HT 'skarn-like' magnetite + calcsilicate assemblages overprinted by hematite-sulfide-bearing assemblages are reported from the Murdie Murdie prospect $\sim 15 \mathrm{~km}$ SE of Island Dam, at the Titan prospect $\sim 25 \mathrm{~km}$ NNE of Olympic Dam, and at the Emmie Bluff prospect $\sim 50 \mathrm{~km} \mathrm{SW}$ of Island Dam. All are hosted within metasediments correlated to the Wallaroo Group (Gow et al. 1994; Bastrakov et al. 2007). Further to the southwest, outside the Olympic $\mathrm{Cu}-\mathrm{Au}$ Province, magnesian skarns are a conspicuous lithology in epithermal precious-(base) metal deposits, e.g., at the Paris prospect (Paul et al. 2015).

The mineralogical and iron-oxide trace element data reported here share many similarities with those from other IOCG deposits in South Australia (Ciobanu et al. 2013; Verdugo-Ihl et al. 2017). For example, silician magnetite from Island Dam resembles that interpreted to represent early alkali-calcic alteration from the 'outer shell' of the Olympic Dam deposit, which also contains elevated $\mathrm{SiO}_{2}, \mathrm{CaO}$, and $\mathrm{MgO}$ (Verdugo-Ihl et al. 2020). Ciobanu et al. (2019) found that oscillatory zoning within this magnetite resulted from nm-scale inclusions of (ferro)actinolite, diopside and epidote, as well as U-, W-(Mo), Y-As- and As-S-nanoparticles. Analogous calcsilicate inclusions might account for the concentrations of lithophile elements in silician magnetite from Island Dam (Fig. 9A), although nanoscale verification would be needed. Dmitrijeva et al. (2019) used multivariate statistical methods to define a Fe-V-Ni-Co signatures for early, deeper magnetite mineralization at the Wirrda Well prospect, a signature also observed for magnetite in the present study. In general, relative enrichment of transition metals and lithophile elements in silician magnetite from Island Dam (Fig. 9A) is characteristic of magnetite associated with deeper HT Ca-Fe alteration in IOCG systems in general (Huang et al. 2018). Study of hematite textures from Olympic Dam (Verdugo-Ihl et al. 2017) identified coarse-grained lamellar hematite, among multiple other textures (e.g., replacement textures and vacuole-filling), which are comparable to those described here from Island Dam. The U-Sn-W-Mo signature in hematite is pervasive throughout all lithologies at Olympic Dam and is an inherent characteristic of IOCG systems in the Olympic Dam district (Courtney-Davies et al. 2019a) and elsewhere (e.g., Verdugo-Ihl et al. 2022).

In addition to iron-oxides, our mineralogical and geochemical characterization of rutile, actinolite, and apatite from Island Dam show that they resemble those from other areas within the Olympic $\mathrm{Cu}-\mathrm{Au}$ Province sharing pronounced $\mathrm{Na}-\mathrm{Ca}-\mathrm{Fe}$ alteration. Rutile (Rt1) from Island Dam displays nearly identical mineral associations (rutile + chlorite + hematite + Ca-REE-phosphates and -fluorocarbonates), trace element enrichments (Nb, Ta, V, $\mathrm{R}$ REY), and REY fractionation trends (upward-sloping) as that in felsic volcanic rocks from the Moonta-Wallaroo area (KontonikasCharos et al. 2014). Such rutile was interpreted to belong to a hydrothermal alteration assemblage associated with an albitization event during the early stages of IOCG mineralization and was found to be an important carrier of trace elements. Formation of W-rich rutile associated with lamellar hematite (Rt2) from Island Dam may represent evolving fluid compositions towards a system richer in W. Similar to the actinolite from Island Dam documented here, the actinolite described by Ismail et al. (2014) from skarns at Hillside is also relatively enriched in $\mathrm{Ni}$ and $\mathrm{Zn}$ and features an upward-sloping, HREE-enriched fractionation trend. Hillside actinolite was interpreted as the replacement product of pyroxene during retrograde skarn formation, coupled with a shift from a HREE- to LREE-dominant system. Apatite from Island Dam displays chondrite-normalized REY fractionation trends featuring LREE-enrichment, HREE-depletion, and strong negative Eu-anomalies, a characteristic feature of early hydrothermal apatite associated with 'deep' and 'distal' mineralization zones at Olympic Dam (Krneta et al. 2017b). Similar apatite is reported from the MoontaWallaroo region and is interpreted as relating to hydrothermal alteration during early IOCG formation throughout the Olympic $\mathrm{Cu}-\mathrm{Au}$ Province (Kontonikas-Charos et al. 2014; Ismail et al. 2014).

The most striking similarity between Island Dam and other IOCG systems in the Olympic Province is the relative timing of alteration. Reviews of IOCG-(U) metallogeny throughout the Olympic Cu-Au Province (Skirrow et al. 2007; Reid 2019) found that mineralization within the Mt. Woods Inlier, in the Olympic Dam district, and in the Moonta-Wallaroo district in the south took place between $\sim 1.6$ and $\sim 1.57 \mathrm{Ga}$, coincident with emplacement of the Hiltaba Suite and GRV. Available ages for skarn alteration at Punt Hill $(\sim 1577 \pm 7 \mathrm{Ma}$ Sm-Nd age; Reid et al. 2011) and Hillside (1601 \pm 16 Ma titanite age and $1584 \pm 7 \mathrm{Ma}$ allanite age; Gregory et al. 2011) also show that skarn-style alteration and mineralization is temporally synchronous with $\sim 1.6 \mathrm{Ga}$ Hiltaba Suite magmatism. The hematite and apatite ages obtained here statistically overlap 
with one another and imply a hydrothermal event at $\sim 1590 \mathrm{Ma}$. Intergrowths between sulfides and lamellar hematite within skarn also imply that the IOCG-U mineralization was deposited at $1590 \mathrm{Ma}$, supporting the hypothesis that alteration and mineralization at Island Dam belong to the same hydrothermal event across the Olympic $\mathrm{Cu}-\mathrm{Au}$ Province.

\section{Conclusions}

Skarn assemblages of actinolite/phlogopite + K-feldspar + magnetite suggest the presence of calcareous protoliths at Island Dam and indicate HT alkali-calcic alteration in the early stages of IOCG mineralization, as seen in other deposits throughout the Olympic $\mathrm{Cu}-\mathrm{Au}$ Province and in other IOCG terranes. Oscillatory zoned magnetite in skarn is enriched in $\mathrm{Si}$ along with $\mathrm{V}, \mathrm{Ni}$ and $\mathrm{Co}$, comparable with that observed in the outer shell of Olympic Dam and at Wirrda Well, and consistent with early stages of IOCG mineralization. The geochemical signatures of hematite from skarn and arkose/Fe-rich metasedimentary rocks share a common enrichment in granitophile elements. Whereas this signature is expected of hematite formation in IOCG systems associated with the $\sim 1.6 \mathrm{Ga}$ Hiltaba event, the relative enrichment in $\mathrm{As}, \mathrm{Sb}, \mathrm{Ni}$, and $\mathrm{Co}$ is specific to iron-oxides from arkose. Overprinting features and chemical signatures (As, $\mathrm{Sb}, \mathrm{Ni}, \mathrm{Co}$ ) of polygranular hematite in arkose can be attributed to pre-existing iron-rich (BIF?) lithologies, with Mo-U signatures either indicating interaction with $\sim 1.6$ Ga Hiltaba-derived hydrothermal fluids, or fluids from an earlier source (e.g., 1760 Ma granites). The timing of alteration/mineralization is constrained to $1593 \pm 28$ Ma by directly dating lamellar hematite intergrown with $\mathrm{Cu}$-sulfides, correlating with the $\sim 1.6 \mathrm{Ga}$ IOCG mineralization event throughout the eastern Gawler Craton. The host metasedimentary rocks at Island Dam are correlated to the ca. $1750 \mathrm{Ma}$ Wallaroo Group based on lithology and by stratigraphic constraints given by the underlying 1860 Ma Donington Suite granite and our new $\mathrm{U}-\mathrm{Pb}$ ages for mineralization.

Supplementary Information The online version contains supplementary material available at https://doi.org/10.1007/s00126-022-01096-1.

Acknowledgements Jocelyn McPhie is thanked for assistance during drill core logging. We appreciate constructive comments from Claire Wade, an anonymous reviewer, Associate Editor Pasi Eilu, and Editorin-Chief Georges Beaudoin, which significantly assisted improvement of this manuscript.

Funding Open Access funding enabled and organized by CAUL and its Member Institutions. This is a contribution to the 'FOX' project (Trace elements in iron-oxides: deportment, distribution and application in ore genesis, geochronology, exploration and mineral processing), supported by BHP Olympic Dam and the South Australian Government Mining and Petroleum Services Centre of Excellence.

Open Access This article is licensed under a Creative Commons Attribution 4.0 International License, which permits use, sharing, adaptation, distribution and reproduction in any medium or format, as long as you give appropriate credit to the original author(s) and the source, provide a link to the Creative Commons licence, and indicate if changes were made. The images or other third party material in this article are included in the article's Creative Commons licence, unless indicated otherwise in a credit line to the material. If material is not included in the article's Creative Commons licence and your intended use is not permitted by statutory regulation or exceeds the permitted use, you will need to obtain permission directly from the copyright holder. To view a copy of this licence, visit http://creativecommons. org/licenses/by/4.0/.

\section{References}

Allen S, McPhie J, Ferris G, Simpson C (2008) Evolution and architecture of a large felsic igneous province in western Laurentia: the 1.6 Ga Gawler Range Volcanics, South Australia. J Volc Geotherm Res 172:132-147

Barton MD (2014) Iron oxide(-Cu-Au-REE-P-Ag-U-Co) systems. In: Turekian K, Holland H, Scott SD (ed) Treatise on Geochemistry, vol 13, $2^{\text {nd }}$ ed, Elsevier, New York:515-541

Bastrakov EN, Skirrow RG, Davidson GJ (2007) Fluid evolution and origins of iron oxide $\mathrm{Cu}-\mathrm{Au}$ prospects in the Olympic Dam district, Gawler Craton, South Australia. Econ Geol 102:1415-1440

Blissett AH, Creaser RA, Daly SJ, Flint DJ, Parker AJ (1993) Gawler Range Volcanics. In: Drexel JF, Preiss WV, Parker AJ (ed) The Geology of South Australia. vol 1, The Precambrian: Adelaide, Geol Surv South Australia, Bulletin 54, pp. 107-131. https://sarig basis.pir.sa.gov.au/WebtopEw/ws/samref/sarig1/image/DDD/ BULL054(V1).pdf

Cherry AR, Ehrig K, Kamenetsky VS, Ehrig K, McPhie J, Crowley JL, Kamenetsky MB (2018) Precise geochronological constraints on the origin, setting and incorporation of ca. $1.59 \mathrm{Ga}$ surficial facies into the Olympic Dam Breccia Complex, South Australia. Precambr Res 315:162-178

Ciobanu CL, Verdugo-Ihl MR, Slattery A, Cook NJ, Ehrig K, Courtney-Davies L, Wade BP (2019) Silician magnetite: Si-Fe- nanoprecipitates and other mineral inclusions in magnetite from the Olympic Dam deposit, South Australia. Minerals 9:311

Ciobanu CL, Wade BP, Cook NJ, Schmidt Mumm A, Giles D (2013) Uranium-bearing hematite from the Olympic Dam $\mathrm{Cu}-\mathrm{U}-\mathrm{Au}$ deposit, South Australia: a geochemical tracer and reconnaissance $\mathrm{Pb}-\mathrm{Pb}$ geochronometer. Precambr Res 238:129-147

Ciobanu CL, Verdugo-Ihl MR, Cook NJ, Ehrig K, Slattery A, Courtney-Davies L (2022) Ferro-tschermakite with polysomatic chainwidth disorder identified in silician magnetite from Wirrda Well, South Australia: a HAADF STEM Study. Am Mineral. https://doi. org/10.2138/am-2022-7975(inpress)

Conor C, Raymond O, Baker T, Teale G, Say P, Lowe G (2010) Alteration and mineralisation in the Moonta-Wallaroo $\mathrm{Cu}-\mathrm{Au}$ mining field region, Olympic Domain, South Australia. In: Porter TM (ed) Hydrothermal Iron Oxide Copper-Gold and Related Deposits: A Global Perspective 3. PGC Publishing, Adelaide, pp 1-24

Courtney-Davies L, Ciobanu CL, Verdugo-Ihl MR, Dmitrijeva M, Cook NJ, Ehrig K, Wade BP (2019) Hematite geochemistry and geochronology resolve genetic and temporal links among ironoxide copper gold systems, Olympic Dam district, South Australia. Precambr Res 335:105480

Courtney-Davies L, Tapster SR, Ciobanu CL, Cook NJ, Verdugo-Ihl MR, Ehrig KJ, Kennedy AK, Gilbert SE, Condon DJ, Wade BP (2019b) A multi-technique evaluation of hydrothermal hematite $\mathrm{U}-\mathrm{Pb}$ isotope systematics: implications for ore deposit geochronology. Chem Geol 513:54-72 
Courtney-Davies L, Ciobanu CL, Tapster SR, Cook NJ, Ehrig K, Crowley JL, Verdugo-Ihl MR, Wade BP, Condon DJ (2020a) Opening the magmatic-hydrothermal window: high-precision $\mathrm{U}-\mathrm{Pb}$ geochronology of the Mesoproterozoic Olympic dam $\mathrm{Cu}-\mathrm{U}-\mathrm{Au}-\mathrm{Ag}$ deposit, South Australia. Econ Geol 115:1855-1870

Courtney-Davies L, Ciobanu CL, Verdugo-Ihl MR, Cook NJ, Ehrig KJ, Wade BP, Zhu ZY, Kamenetsky VS (2020b) 1760 Ma magnetitebearing protoliths in the Olympic Dam deposit, South Australia: implications for ore genesis and regional metallogeny. Ore Geol Rev 118:103337

Cowley W, Conor C, Zang W (2003) New and revised Proterozoic stratigraphic units on northern Yorke Peninsula. MESA J 29:4658. https://sarigbasis.pir.sa.gov.au/WebtopEw/ws/samref/sarig1/ image/DDD/MESAJ029046-058.pdf

Creaser RA (1989) The geology and petrology of Middle Proterozoic felsic magmatism of the Stuart Shelf, South Australia: unpublished Ph.D. thesis, Melbourne, La Trobe University, $434 \mathrm{p}$

Direen NG, Lyons P (2007) Crustal setting of iron oxide Cu-Au mineral systems of the Olympic Dam district, South Australia: insights from potential field data. Econ Geol 102:1397-1414

Dmitrijeva M, Ciobanu C, Ehrig K, Cook N, Metcalfe A, VerdugoIhl M, McPhie J (2019) Mineralization-alteration footprints in the Olympic Dam IOCG district South Australia: the Acropolis prospect. J Geochem Explor 205:106333

Dmitrijeva MD, Ciobanu CL, Ehrig K, Cook NJ, Verdugo-Ihl MR, Metcalfe AV, Kamenetsky VS, McPhie J, Carew M (2022) Geochemical data analysis of iron-oxide copper gold mineralization, Wirrda Well prospect, South Australia. Econ Geol (in press), South Australia

Ehrig K, McPhie J, Kamenetsky V (2012) Geology and mineralogical zonation of the Olympic Dam iron oxide $\mathrm{Cu}-\mathrm{U}-\mathrm{Au}-\mathrm{Ag}$ deposit, South Australia: In: Hedenquist JW, Harris M, Camus F (eds) Geology and genesis of major copper deposits and districts of the world, a Tribute to Richard Sillitoe. SEG Spec Publ 16:237-268.

Ehrig K, Kamenetsky V, McPhie J, Cook NJ, Ciobanu CL (2017) Olympic Dam iron-oxide $\mathrm{Cu}-\mathrm{U}-\mathrm{Au}-\mathrm{Ag}$ deposit. In: Phillips GN (ed) Australian Ore Deposits. AusIMM, Melbourne, pp. 601-610

Fabris A, Katona L, Georgia G, Reed G, Keeping T, Gouthas G, Swain $\mathrm{G}$ (2018) Characterisation and mapping of $\mathrm{Cu}-\mathrm{Au}$ skarn systems in the Punt Hill region, Olympic Cu-Au Province. MESA 87:1527. https://sarigbasis.pir.sa.gov.au/WebtopEw/ws/samref/sarig1/ image/DDD/MESAJ087015-027.pdf

Foden J, Elburg MA, Dougherty-Page J, Burtt A (2006) The timing and duration of the Delamerian Orogeny: correlation with the Ross Orogen and implications for Gondwana Assembly. J Geol 114:189-210

Geological Survey of South Australia (2019) SARIG Database. https:// map.sarig.sa. gov.au/

Gow PA, Wall VJ, Oliver NHS, Valenta RK (1994) Proterozoic iron oxide (Cu-U-Au-REE) deposits: Further evidence of hydrothermal origin. Geology 22:633-636

Gregory CJ, Reid AJ, Say P, Teale GS (2011) U-Pb geochronology of hydrothermal allanite and titanite and magmatic zircon from the Hillside $\mathrm{Cu}-\mathrm{Au}$ deposit, Yorke Peninsula. In: Reid AJ, Jagodzinski EA (ed) PACE geochronology: results of Collaborative Geochronology Projects 2009-10 South Australia. Department of Primary Industries and Resources, pp. 95-126 (Report Book 2011/00003). https://sarigbasis.pir.sa.gov.au/WebtopEw/ws/samref/sarig1/image/DDD/RB201100003.pdf

Halpin JA, Reid AJ (2016) Earliest Paleoproterozoic high-grade metamorphism and orogenesis in the Gawler Craton, South Australia: the southern cousin in the Rae family? Precambr Res 276:123144. https://doi.org/10.1016/j.precamres.2016.02.001

Hayward N, Skirrow RG (2010) Geodynamic setting and controls on iron oxide $\mathrm{Cu}-\mathrm{Au}( \pm \mathrm{U})$ ore in the Gawler Craton, South Australia. In: Porter TM (ed) Hydrothermal Iron Oxide Copper-Gold and
Related Deposits: A Global Perspective, vol 3. PGC Publishing, Adelaide, pp 1-27

Hitzman MW, Oreskes N, Einaudi MT (1992) Geological characteristics and tectonic setting of Proterozoic iron oxide $(\mathrm{Cu}-\mathrm{U}-\mathrm{Au}-\mathrm{REE})$ deposits. Precambr Res 58:214-287

Huang X-W, Boutroy É, Makvandi S, Beaudoin G, Corriveau L, De Toni A (2018) Trace element composition of iron oxides from IOCG and IOA deposits: relationship to hydrothermal alteration and deposit subtypes. Mineral Deposita 54:525-552

Ismail R, Ciobanu CL, Cook NJ, Teale GS, Giles D, Mumm AS, Wade B (2014) Rare earths and other trace elements in minerals from skarn assemblages, Hillside iron oxide-copper-gold deposit, Yorke Peninsula, South Australia. Lithos 184-187:456-477

Jackson SE, Pearson NJ, Belousova EA, Griffin WL (2004) The application of laser ablation-inductively coupled plasma-mass spectrometry (LA-ICP-MS) to in situ U-Pb geochronology. Chem Geol 211:47-69

Jagodzinski EA (2005) Compilation of SHRIMP U-Pb geochronological data, Olympic Domain, Gawler Craton, South Australia, 2001-2003. Geoscience Australia Record 2005/20.

Keyser WM, Ciobanu CL, Cook NJ, Courtney-Davies L, Ehrig K, Gilbert S, McPhie J (2017) Links between sedimentary protoliths and IOCG-skarn alteration, Island Dam, South Australia. In: Mineral Resources to Discover, Proceeding of the 14th SGA Biennial Meeting, 20-23 August 2017, Québec City, Canada: pp. 935-938. https://e-sga.org/index.php?eID =tx_nawsecured $1 \& \mathrm{u}=0 \& \mathrm{~g}=0 \& \mathrm{t}=1635503595 \& \mathrm{hash}=\mathrm{d} 6 \mathrm{ea} 0954 \mathrm{a} 01 \mathrm{deabfda} 3 \mathrm{~b}$ 92df099f613267da0158\&file $=$ fileadmin/sga/Shop_-_Downl oads/SGA_Abstract_Volumes/2017_Quebec/SGA_Que\%CC\% 81bec_2017_vol3.pdf

Kontonikas-Charos A, Ciobanu CL, Cook NJ (2014) Albitization and redistribution of REE and Y in IOCG systems: insights from Moonta-Wallaroo, Yorke Peninsula, South Australia. Lithos 208-209:178-201

Kontonikas-Charos A, Ciobanu CL, Cook NJ, Ehrig K, Ismail R, Krneta S, Basak A (2018) Feldspar mineralogy and rare-earth element (re)mobilization in iron-oxide copper gold systems from South Australia: a nanoscale study. Mineral Mag 82:S173-S197

Krneta S, Ciobanu CL, Cook NJ, Ehrig K, Kontonikas-Charos A (2017a) The Wirrda Well and Acropolis prospects Gawler Craton, South Australia: insights into evolving fluid conditions through apatite chemistry. J Geochem Explor 181:276-291

Krneta S, Ciobanu CL, Cook NJ, Ehrig K, Kontonikas-Charos A (2017b) Rare earth element behaviour in apatite from the Olympic Dam Cu-U-Au-Ag deposit, South Australia. Minerals 7:135

Leake BE, Woolley AR, Arps CES, Birch WD, Gilbert MC, Grice JD, Hawthorne FC, Kato A, Kisch HJ, Krivovichev VG, Linthout K, Laird J, Mandarino JA, Maresch WV, Nickel EH, Schumacher JC, Smith DC, Stephenson NCN, Ungaretti L, Whittaker EJW, Youzhi G (1997) Nomenclature of amphiboles: report of the subcommittee on amphiboles of the international mineralogical association, commission on new minerals and mineral names. Can Mineral $35: 219-246$

Ludwig KR (2012) Isoplot/Ex rev. 4.1: A geochronological toolkit for Microsoft Excel. Berkeley Geochronology Centre Special Publication No. 5, 75. Berkeley Geochronology Centre: Berkeley, California

Makvandi S, Huang X, Beaudoin G, Quirt D, Ledru P, Fayek M (2021) Trace element signatures in hematite and goethite associated with the Kiggavik-Andrew Lake structural trend U deposits (Nunavut, Canada). Mineral Deposita 56:509-535

McDonough WF, Sun SS (1995) The composition of the Earth. Chem Geol 120:223-253

McDowell FW, McIntosh WC, Farley KA (2005) A precise Ar40-Ar-39 reference age for the Durango apatite (U-Th)/He and fission-track dating standard. Chem Geol 214:249-263 
McPhie J, Ehrig KJ, Kamenetsky MB, Crowley JL, Kamenetsky VS (2020) Geology of the Acropolis prospect, South Australia, constrained by high-precision CA-TIMS ages. Austral J Earth Sci 67:699-716

Oreskes N, Einaudi MT (1992) Origin of hydrothermal fluids at Olympic Dam: preliminary results from fluid inclusions and stable isotopes. Econ Geol 87:64-90. https://doi.org/10.2113/gsecongeo. 87.1 .64

Paton C, Hellstrom J, Paul B, Woodhead J, Hergt J (2011) Iolite: freeware for the visualisation and processing of mass data. $\mathrm{J}$ Anal at Spectrom 26:2508-2518

Paul MW, Cook NJ, Ciobanu CL, Anderson J, Murray J (2015) Preliminary mineralogical investigations of the Paris silver deposit, Northern Eyre Peninsula, South Australia. Proc Mineral Resources in a Sustainable World, $13^{\text {th }}$ Biennial SGA Conf., Nancy, France, August 2015. https://e-sga.org/index.php?eID= tx_nawsecuredl $\& \mathrm{u}=0 \& \mathrm{~g}=0 \& \mathrm{t}=1637921181 \& \mathrm{hash}=4 \mathrm{af} 75 \mathrm{df} 2 \mathrm{de}$ f792c7c79963a8101b8fcfae8c7a41\&file=fileadmin/sga/Shop_-Downloads/SGA_Abstract_Volumes/2015_Nancy/SGA_Nancy_ 2015_vol1.pdf

Preiss WV (1993) Neoproterozoic. In: Drexel JF, Preiss WV, Parker AJ (ed) The Geology of South Australia, vol 1, The Precambrian. Geol Surv South Australia Bull 54, p. 170-203. https://sarigbasis. pir.sa.gov.au/WebtopEw/ws/samref/sarig1/image/DDD/BULL0 54(V1).pdf

Pankhurst MP, Schaefer BF, Betts PG, Phillips N, Hand M (2011) A Mesoproterozoic continental flood rhyolite province, the Gawler Ranges, Australia: the end member example of the Large Igneous Province clan. Solid Earth 2:1-9. https://doi.org/10.5194/ se-2-25-2011

Reid A (2019) The Olympic Cu-Au Province, Gawler Craton: a review of the lithospheric architecture, geodynamic setting, alteration systems, cover successions and prospectivity. Minerals 9:371

Reid A, Hand M, Jagodzinski E, Kelsey D, Pearson N (2008) Paleoproterozoic orogenesis in the southeastern Gawler Craton, South Australia. Austr J Earth Sci 55:449-471

Reid A, Smith RN, Baker T, Jagodzinski EA, Selby D, Gregory CJ, Skirrow RG (2013) Re-Os dating of molybdenite within hematite breccias from the Vulcan $\mathrm{Cu}-\mathrm{Au}$ prospect, Olympic $\mathrm{Cu}-\mathrm{Au}$ province, South Australia. Econ Geol 108:883-894

Reid AJ, Fabris A (2015) Influence of preexisting low metamorphic grade sedimentary successions on the distribution of iron oxide copper-gold mineralization in the Olympic $\mathrm{Cu}-\mathrm{Au}$ Province, Gawler Craton. Econ Geol 110:2147-2157

Reid AJ, Swain GS, Mason D, Maas R (2011) Nature and timing of $\mathrm{Cu}-\mathrm{Au}-\mathrm{Zn}-\mathrm{Pb}$ mineralisation at Punt Hill, eastern Gawler Craton. MESA J 60:7-17. https://sarigbasis.pir.sa.gov.au/WebtopEw/ws/ samref/sarig1/image/DDD/MESAJ060007-017.pdf

Schoene B, Bowring SA (2006) U-Pb systematics of the McClure Mountain syenite: thermochronological constraints on the age of the ${ }^{40} \mathrm{Ar} /{ }^{39} \mathrm{Ar}$ standard MMhb. Contrib Mineral Petrol 151:615-630

Skirrow RG, Bastrakov EN, Barovich K, Fraser GL, Creaser RA, Fanning CM, Raymond OL, Davidson GJ (2007) Timing of iron oxide $\mathrm{Cu}-\mathrm{Au}-(\mathrm{U})$ hydrothermal activity and $\mathrm{Nd}$ isotope constraints on metal sources in the Gawler Craton, South Australia. Econ Geol 102:1441-1470

Skirrow RG, Bastrakov E, Davidson GJ, Raymond O, Heithersay P (2002) Geological framework, distribution and controls of Feoxide $\mathrm{Cu}-\mathrm{Au}$ deposits in the Gawler craton. Part II: Alteration and mineralisation. In: Porter TM (ed) Hydrothermal Iron Oxide Copper-Gold and Related Deposits, vol 2. PGC Publishing, Adelaide, pp 33-47

Skirrow RG, Van Der Wielen SE, Champion DC, Czarnota K, Thiel S (2018) Lithospheric architecture and mantle metasomatism linked to iron oxide $\mathrm{Cu}-\mathrm{Au}$ ore formation: multidisciplinary evidence from the Olympic Dam Region, South Australia. Geochem Geophys Geosyst 19:2673-2705

Swain G, Woodhouse A, Hand M, Barovich K, Schwarz M, Fanning CM (2005) Provenance and tectonic development of the late Archaean Gawler Craton, Australia; U-Pb zircon, geochemical and Sm-Nd isotopic implications. Precambr Res 141:106-136. https://doi.org/10.1016/j.precamres.2005.08.004

Vassallo JJ, Wilson CJL (2002) Palaeoproterozoic regional-scale noncoaxial deformation: an example from eastern Eyre Peninsula, South Australia. J Structural Geol 24:1-24. https://doi.org/10. 1016/S0191-8141(01)00043-8

Verdugo-Ihl MR, Ciobanu CL, Cook NJ, Ehrig KJ, Courtney-Davies L, Gilbert S (2017) Textures and U-W-Sn-Mo signatures in hematite from the Olympic Dam Cu-U-Au-Ag deposit, South Australia: defining the archetype for IOCG deposits. Ore Geol Rev 91:173-195

Verdugo-Ihl MR, Ciobanu CL, Cook NJ, Ehrig K, Courtney-Davies L (2020) Defining early stages of IOCG systems: evidence from iron-oxides in the outer shell of the Olympic Dam deposit, South Australia. Mineral Deposita 55:429-452

Verdugo-Ihl M, Ciobanu CL, Courtney-Davies L, Cook NJ, Slattery A, Ehrig K, Tornos F, Hanchar JM (2022) U-Pb geochronology and mineralogy of hematite from Mantoverde and Carmen de Cobre. Northern Chile: constraints on Andean IOCG mineralization Econ Geol. https://doi.org/10.5382/econgeo.4903

Williams PJ, Kendrick MA, Xavier RP (2010) Sources of ore fluid components in IOCG deposits. In: Porter TM (ed) Hydrothermal Iron Oxide Copper-Gold and Related Deposits: A Global Perspective, vol 3. PGC Publishing, Adelaide, pp 107-116

Wingate MTD, Campbell IH, Compston W, Gibson GM (1998) Ion microprobe $\mathrm{U}-\mathrm{Pb}$ ages of Neoproterozoic basaltic magmatism in south-central Australia and implications for the breakup of Rodinia. Precambr Res 87:135-159

Zang W (2002) Late Palaeoproterozoic Wallaroo Group and early Mesoproterozoic mineralization in the Moonta Domain, eastern Gawler Craton, South Australia. South Australia, Department of Primary Industries and Resources Report Book, 2002/001. https:// sarigbasis.pir.sa.gov.au/WebtopEw/ws/samref/sarig1/image/DDD/ RB200200001.pdf

Publisher's Note Springer Nature remains neutral with regard to jurisdictional claims in published maps and institutional affiliations. 